Aus dem Gerichtsärztlichen Institut der Medizinischen Fakultäl Okayama

(Vorstand: Prof. Dr. C. Endoh).

\title{
Über das Verhalten des Zuckers, der Milehsäure und des \\ Phosphors des Blutes bei durch Avertinklystier \\ narkotisierten Kaninchen.
}

Von

Kiyosige Mugurums.

Eingegangen am \&. Oktober 1938.

Durch A vertinzufuhr wies der Blutzucker anfangs eine mehr order weniger deutliche Vermehrung auf, verminderte sich dann aber wieder und kehrte 8-12 Studen nach der Zufuhr zum norinalen Wert zurück, wobei der maximale Wert 0.5-1.5 Stunden, der minimale Wert ungefähr 6 Stunden nach der Zufuhr zum Vorschein kam.

Das Verhalten der Blutmilchsäure war nach Zufuhr von Avertin verschieden, d.h. bei einigen Kaninchen erhöhte sie sich, während sie bei anderen fast unverändert blieb order sich sogar etwas verminderte, was achon Fuss und Derra beobachtet hatten. Was den anorganischen Blutphosphor betrifft, so vermehrte er sich bei der A vertinrektalnarkose.

(Autoreferat)

\section{1.}

$616-003.811: 611-018$

\section{正常白鼠二於ヶル清㥓氏耐酸性顆粒ノ研乫}

\section{（第 3 報）}

$$
\text { 鐵・立 }=\text { 銅・耐酸性顆粒二就 テ }
$$

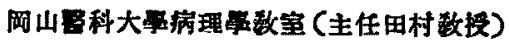

苩莘婎

[昭和 13年10月7日受稿]

$$
\begin{aligned}
& \text { 藉 }
\end{aligned}
$$

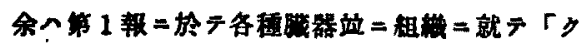

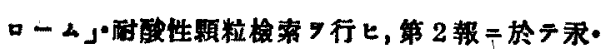

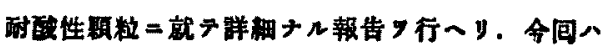


二形態學的 $=$ ヨク類似ン及同氏/化學的检索ノ結

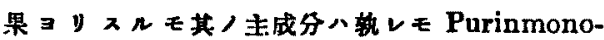
nucleotide $\mathbb{Z}$ ヒ Purinmononucleoside $\exists リ+$

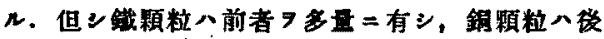
者 7 多量二有ス几點二於テ異ナ几，台东钱顆粒八 Mitochondria 性顆粒中二吸篃サレテ存スルコト

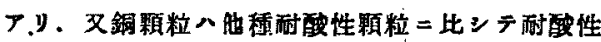

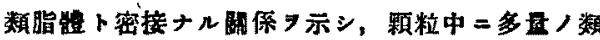

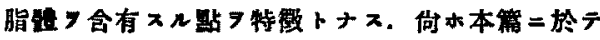

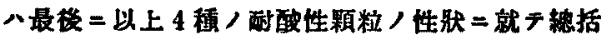

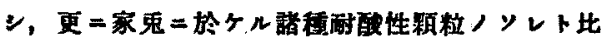

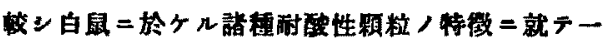
畋七y.

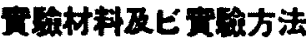

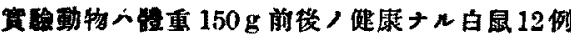

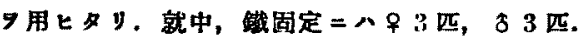

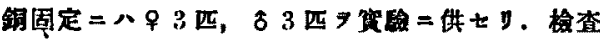

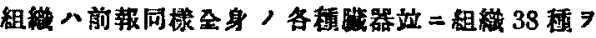

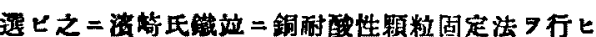
\$y.

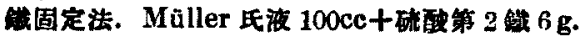
銅固定法. Müller 氏液 $100 \mathrm{cc}+$ 硂酸銅 $8 \mathrm{~g}$.

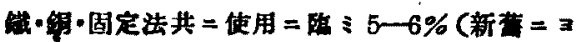

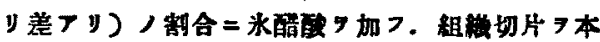
液 $=\mp$ 固定スルコト3日間，整時水洗，援 $10 \%$

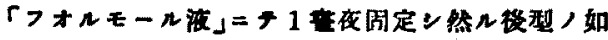
ク「バラフイン切片」ワ製作 ス。染色法八「クロー

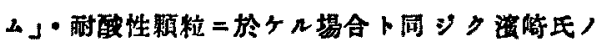
「石炭酸フクシン沃度法」(K.F.J.法) 9 用ヒタリ。 又 Baryt 水分別法，Ciaccio 氏染色法王第 1 尉卜

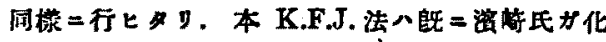
写的二證明セルガ如ク「クローム周定」=本法可施

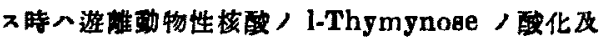
ヒ Enolsierung = 件七「沃度水素酸フクンン」ナ

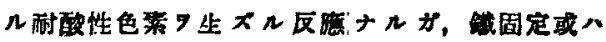

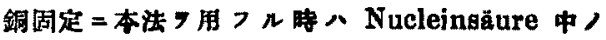

1-Thyminose ノ反魔八抑制女レ Purinmononucleotide 或 Purinmononucleoside $=$ 含有

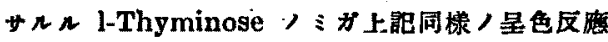

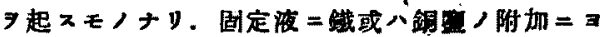

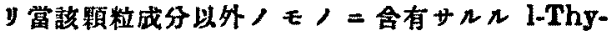
minose，反度が抑制サルルコトハ如何ナル理=

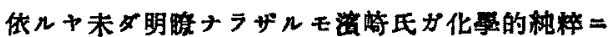

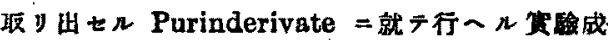

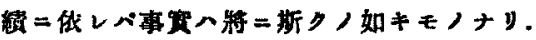

\section{組權的所見}

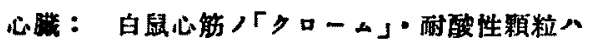

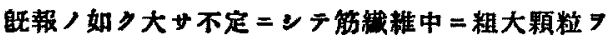

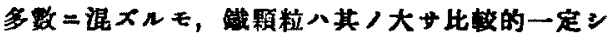

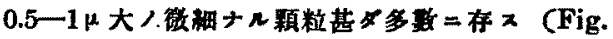
1) 形八稜珄二富山モノ，糊圆形

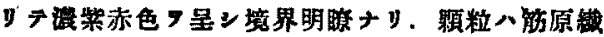
維間二密在ン相粠レハ顆粒ノ時二融合ンテ索㹜ナ

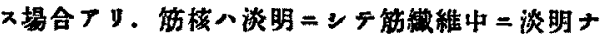

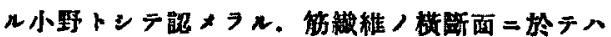
顆粒へ人工的 = 2-3 简感合ンテ現八ルルモノ多

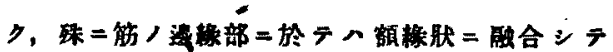

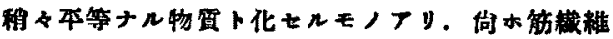
ノ表面二附落ンテ梱微ナル顆粒ノ旧現スルコトナ

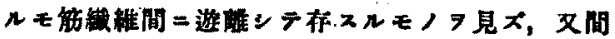

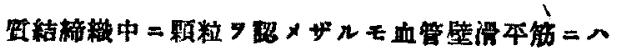

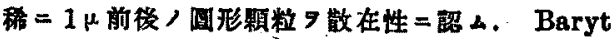

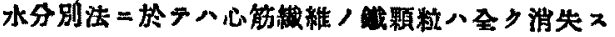

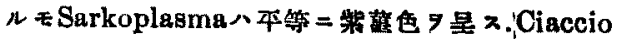

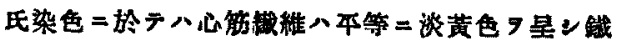
顆䊉ノ中等大ノモノハ「タローム固定」ノ場合 $\equiv$

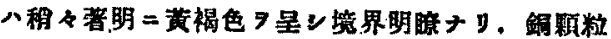

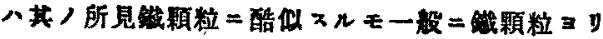

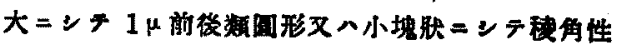

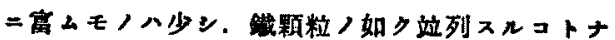

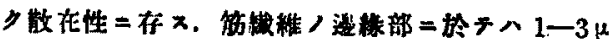

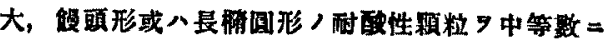




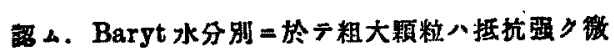

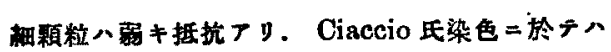

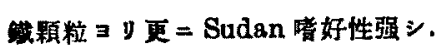

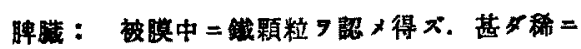

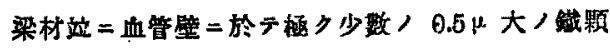

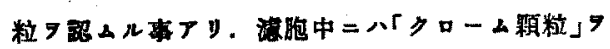

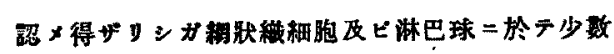

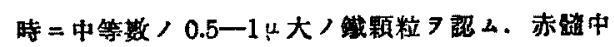

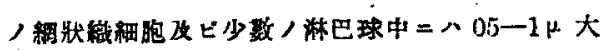

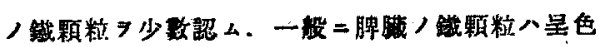

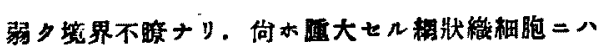

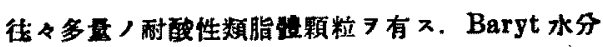

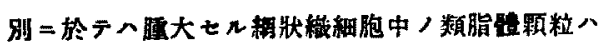

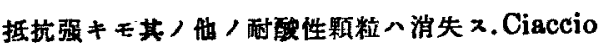

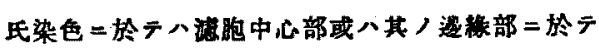

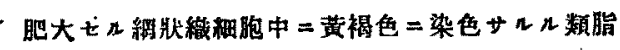

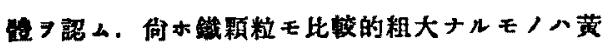
褐色 9 呈シ K.F.J.法二比ンテ程々境界釷利二現

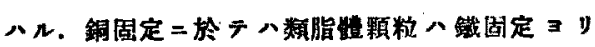

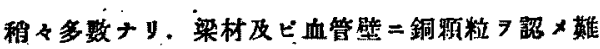

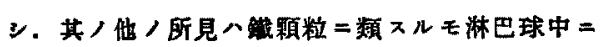

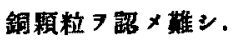

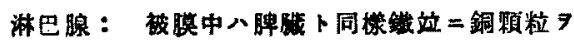

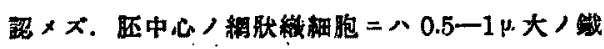

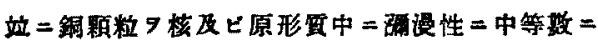

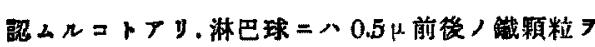
主トシテ核院二外接或八時二內接ンテ少数有ス几

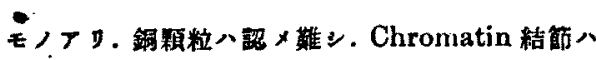

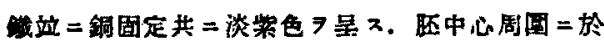

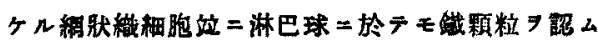

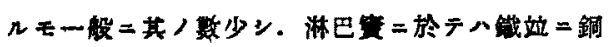

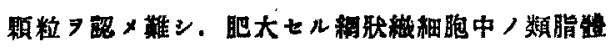

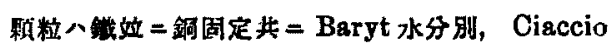

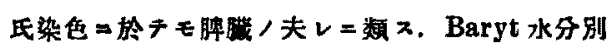

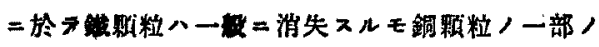

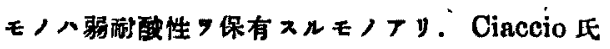

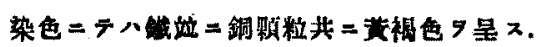

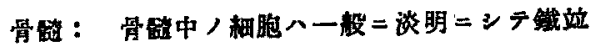

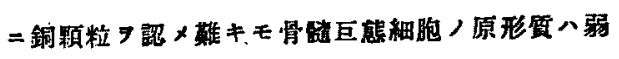
耐酸性 7 有

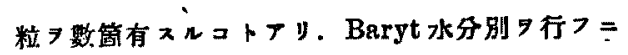

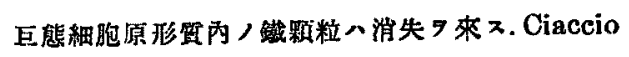

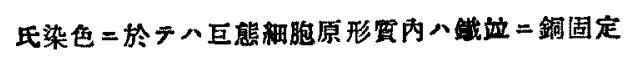
共二淡责色二染色せレ甚ダ不明眭ナルモ践顆粒 撩色三染色サルルワ認ム。

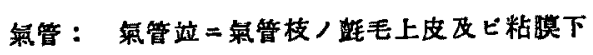

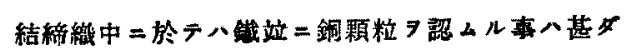
稀

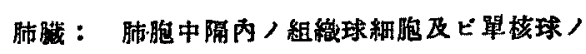
一部ノモノ八 $0.5 \mu$ 前後ノ鐵顆粒 $0.5-1 \mu$ 大ノ類 国形习呈スル銅颗粒 7 少数二有スルコトナリ。愿

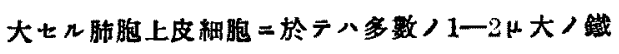
立立二銅顆粒 7 認 二現ハルルそノナ、．就中銅顆粒著明ニシテ顆粒

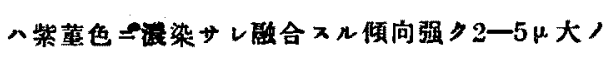
顆粒 9 形成七り．肺ノ楊管枝上皮中 $=八 0.5 \mu$ 前

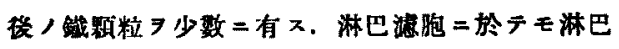

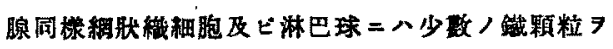
有ス。大ナル血管壁ノ滑平筋中 $=八 0.3-0.5 \mu$ 大䂭 角性 鐵顆粒 $尹$ 中等数=有スルモノフリ。 Baryt

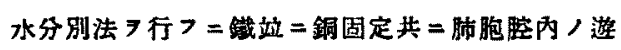

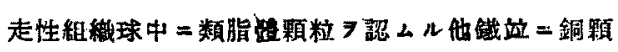
粒八總消失七り，唯淋巴球ノ践顆粒ノミ弱耐酸 性 $\ni$ 保有 ス, Ciaccio 氏染色 7 行

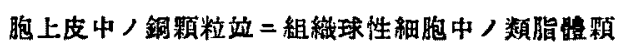

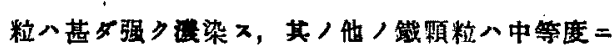
浱染サル几モ淋巴球中八同顆粒八淡裸色 $\mathrm{g}$ 是.

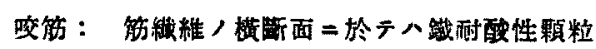

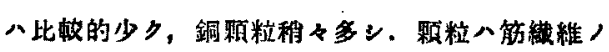

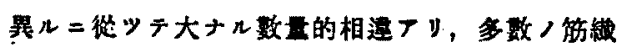

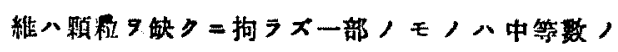

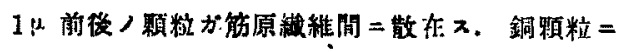

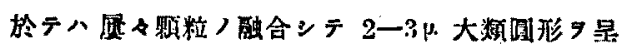
スィもノフリ，份水 Endoplasina 两二八多量， 


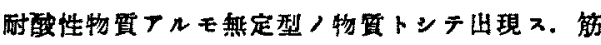

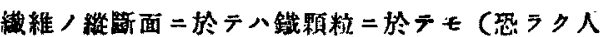

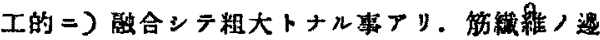

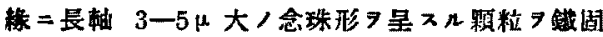

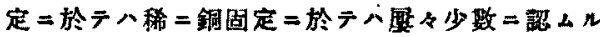
コトアリ.

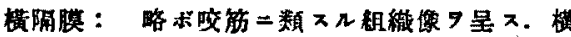

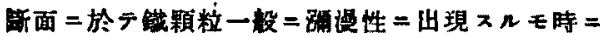

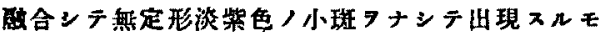

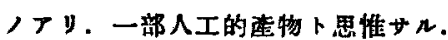

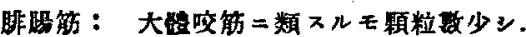

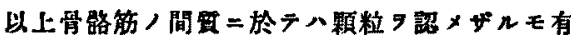

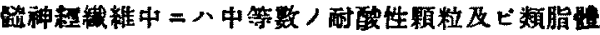

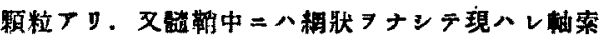

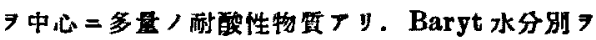

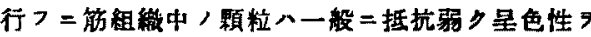
消失スルモ/多キモ粗大ナル顆粒ニ在りテハ一定

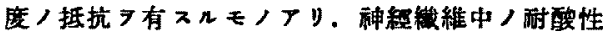

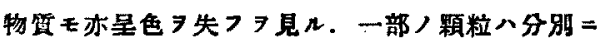

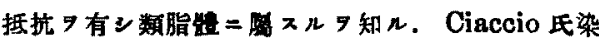

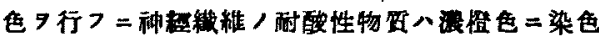

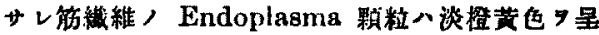

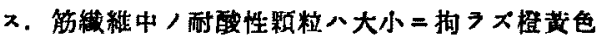
二染色サルルモHämatoxylin 7 用上几時八耧固 定二於テ八 Sarkoplasma 八黑染シ耐酸性顆粒も

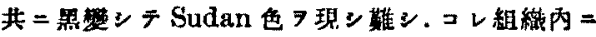

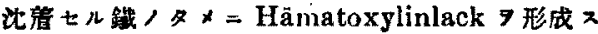
ルモナリ:

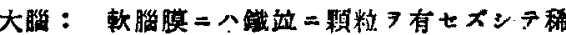

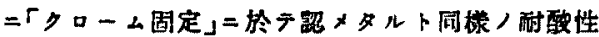

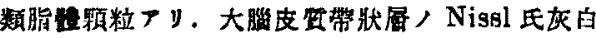

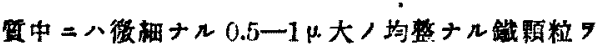

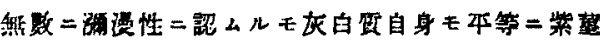
色す是スルガ故二顆精，境界甚ダ不明璄ナリ．銅

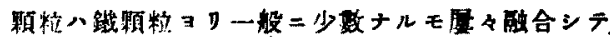

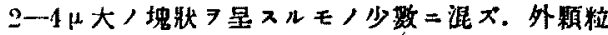

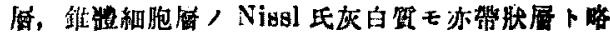

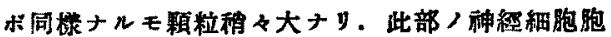

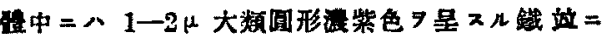
銅顆粒 $\ni$ 少数二認么。就中，銅顆粒二於テハ胎合

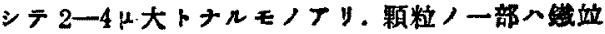

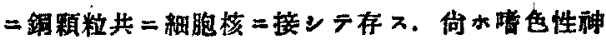
䌌細胞(Chromophile Nervenzellen)为 =八租々

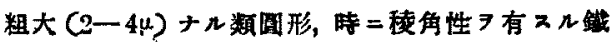

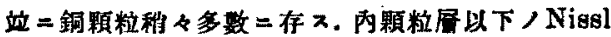

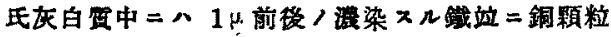

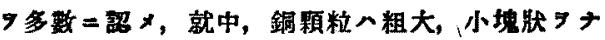

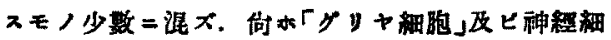

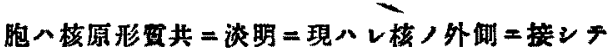

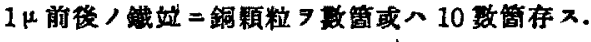

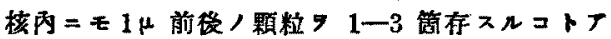

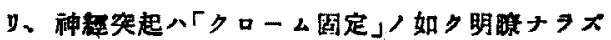
シテ顆粒

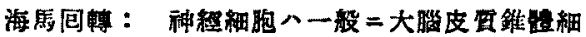

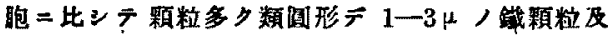

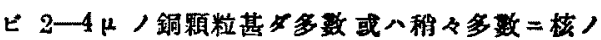

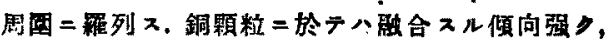
又大ナル顆粒ニンテ中空性或八珢㩆 9 旺スルモノ

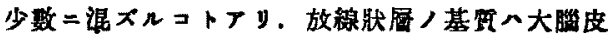

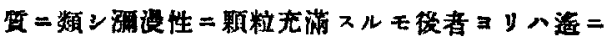

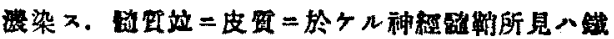
媇二銅顆䊉共二「クロ一么固定」場合二類 ス。

服絡獏：上皮中 $=ヘ 0.5-1 \mu$ 大稜珄時 $=$ 類

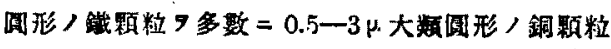

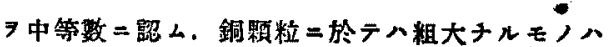
中空性二現ハルルモ/有り． Ependym中二八甚

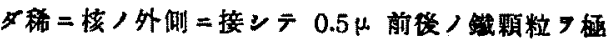

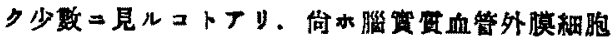

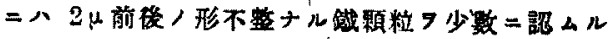

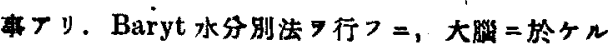
践顆粒八措杭可成弱ク消失スルモ，多キモ Nissl

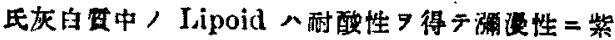
赤色 7 是入，銅頪粒二於テ八践顆籹二於とルコ】

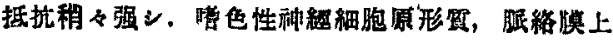


皮原形留及ビ核八可成强名耐酸性

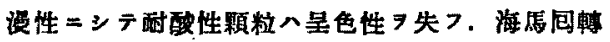

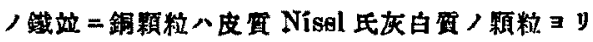
抵抗程々张ン，Ciaccio 氏染色二於テハNisgl 氏

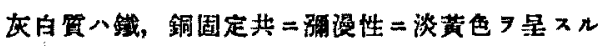

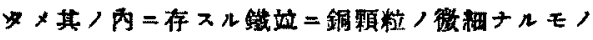

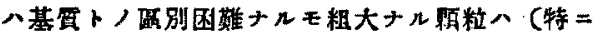

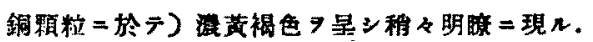
神程相胞八核，原形共 $=$ 淡明

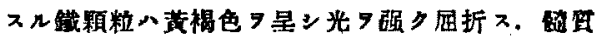
所見八轿・銅固定共ニ「クローム固定」/堨合＝類

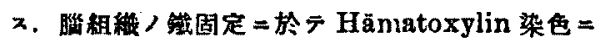

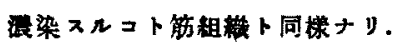

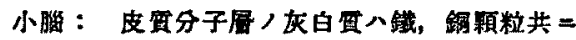

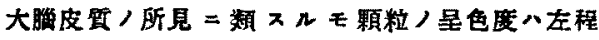

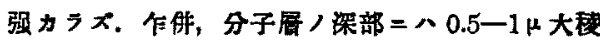

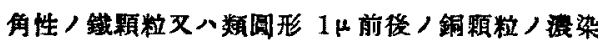

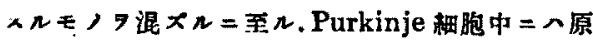

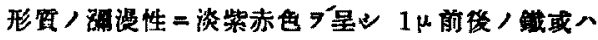

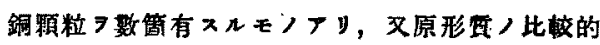

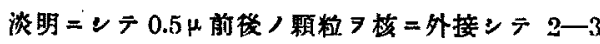

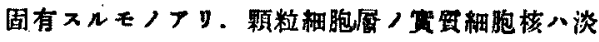
明 ンンテ往は核ニ接シテ $0.3-0.5 \mu$ 大淡紫色す是

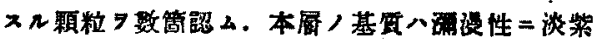

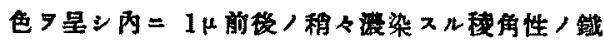

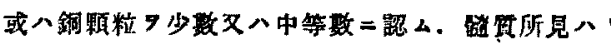

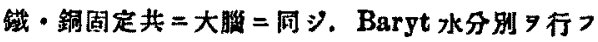

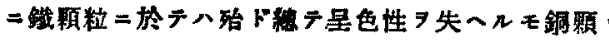

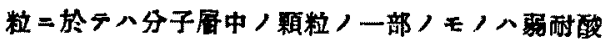

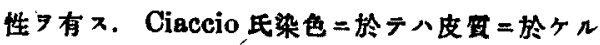

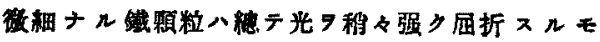

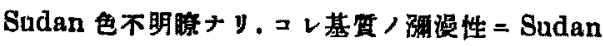

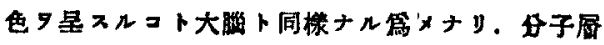

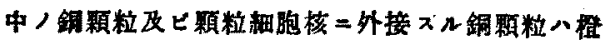
黄色二染色サルルモ顆粒細胞核为ノ銅顆粒八染色 サレx.

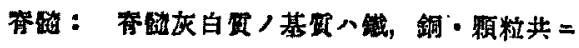

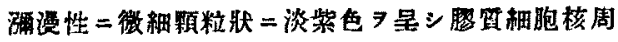
国=ハ「クローム固定」=於テ認メタルガ如キ数大

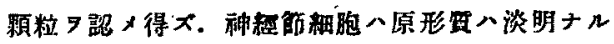
玉時二淡柴色 $刃$ 是スルモノアリ．核八淡明ナルモ

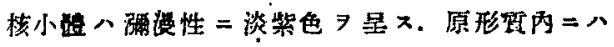

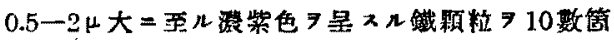

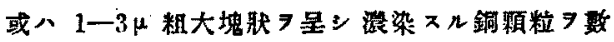

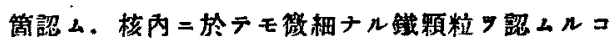

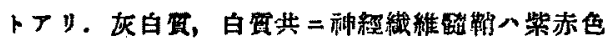
フ是ス几モ践或八銅顆粒 7 認风難シ. Baryt水分

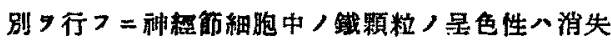

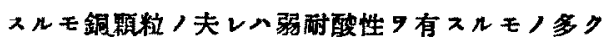

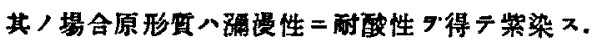
Ciaccio 氏染色 7 行

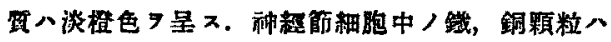

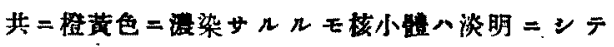
Hãmatoxylin 染色 $=\mathbf{3}$ 青染 。

舌：銅固定=於示粘膜屚平上皮，角化展，梁

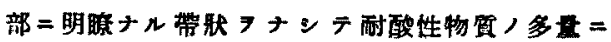
存スルラ見ル。但ン之二顆粒 7 镬メシメザルモ

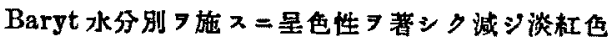
二現八几. Ciaccio 氏染色＝於テ八此部八他，部 ニ比ンテ嚾 = Sudan 㗪好性强ン。舌粘膜表層 =

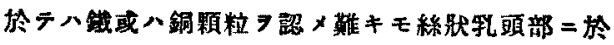

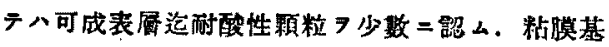

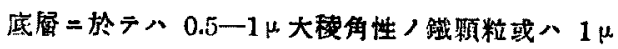

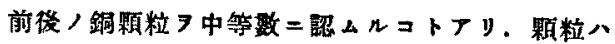
一般二核帨二接ンス八上皮細胞筧界部二㔫スル場

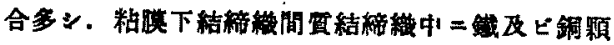
粒 9 现 $\times x$. 舌筋二於テ八筇原維間 $=$ 第赤色 $=$

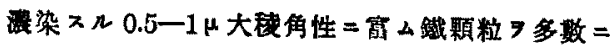

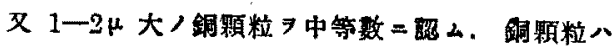

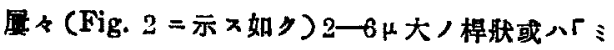

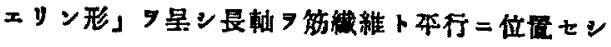

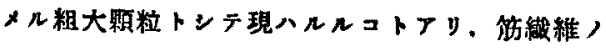

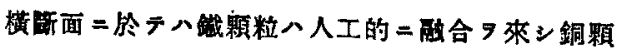

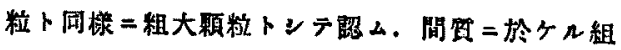




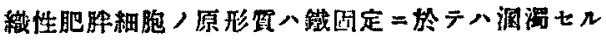
淡紫色

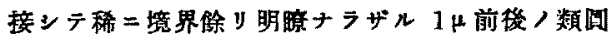
形ノ顆粒 少數存ス几、ノアリ。銅固定=於テハ

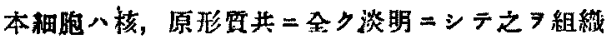
內二於テ检昆スルコト团難ナル程ナリ、動脈壁，

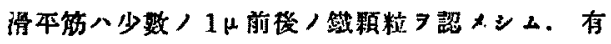

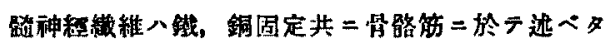

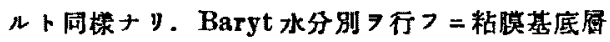

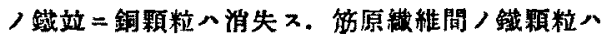

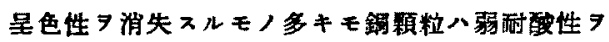

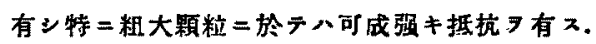

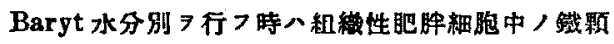

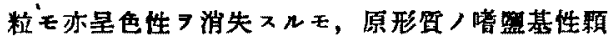

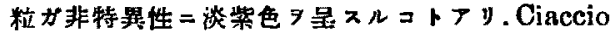

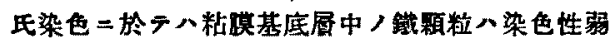

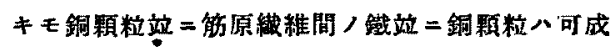

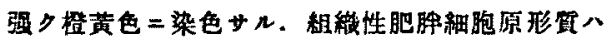

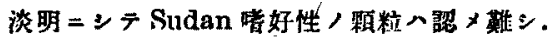

金道：食道粘膜/角化展梁部二八銅固定二於 テの带狀二可成强キ耐酸性 粘膜上皮中處 3 y基底居 $=$ 互》 0.5 - $1 \mu$ 大稜角性

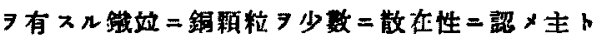

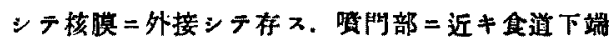
，粘膜上皮 $=>1 \mu$ 前㷋 $/$ 䙳酸性顆粒 9 中等数 $=$

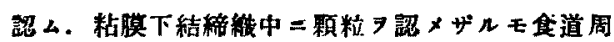

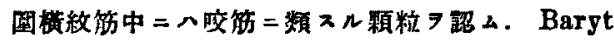

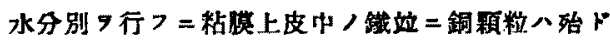
消失 スルモCiaccio 氏染色二於テ八輕度二橙色二 染色甘几.

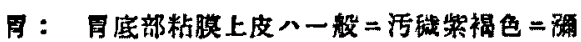

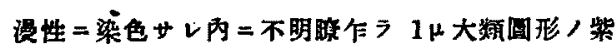
赤色

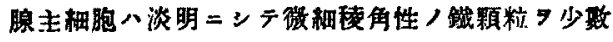

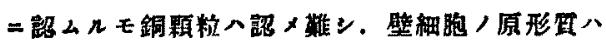
淡紫色二洞澼シテ現ハレ为二赤色調倨 大ノ球形 7 星 $ス 几$ 顆䊉，琙固定 $=八$ 多数二，銅固
定二八少数 $=$ 存シ，核八淡明二現ヘル．国有膜，

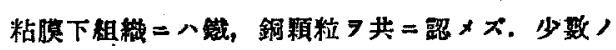
Mastzellen 7 証 $\star$ 其/呈色性舌，場合卜同栐子

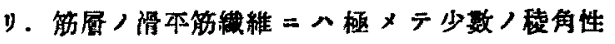

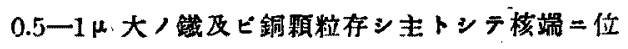

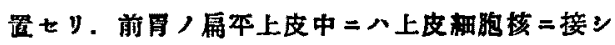

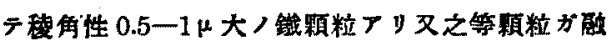

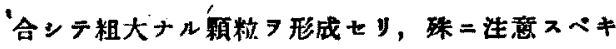

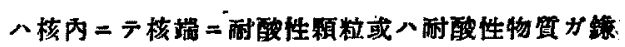

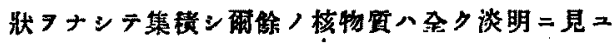

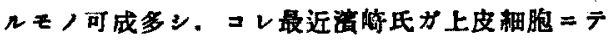

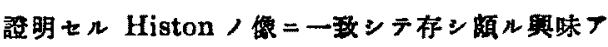

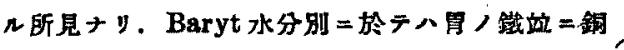
顆粒八共二殆ド消失スれモ壁梱胞ノ「ェオジン睹

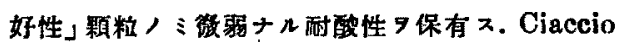
氏染色二於テへ壁緗胞 /原形军八黄棉色二淡染廿

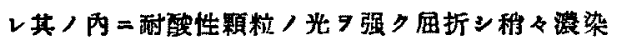
ス八刀喆么。

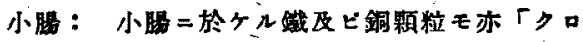

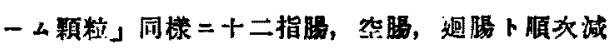
少スルモ「クローム顆粒」二於ケルガ如ク其，差著

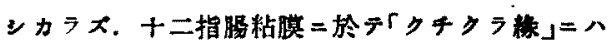

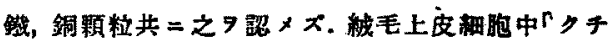

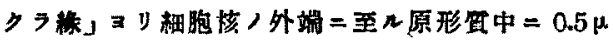

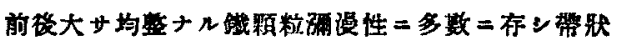

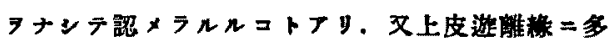
数存 スルコトナリ, 及カカル事ナクシテ $0.5-2 \mu$

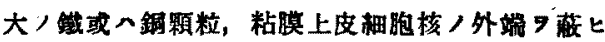

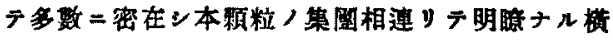

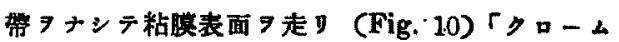

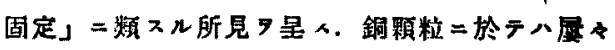

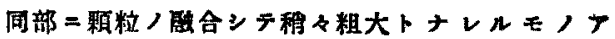

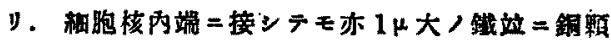

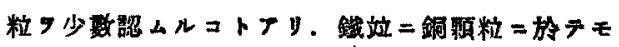

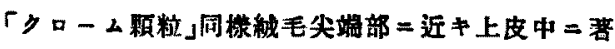

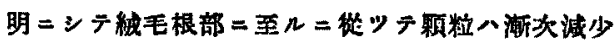

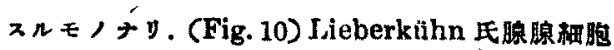


=於テモ0.5-1

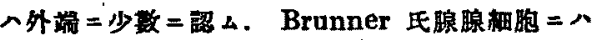

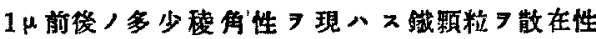

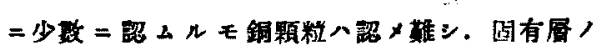
Wanderzellen 殊 $=$ Monozyten $=\lambda 0.5-1.5 \mu$

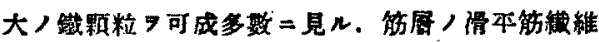
ニ 、 $0.5-1 \mu$ 大ノ鐵顆粒稍 \&不规則 =散在七り.

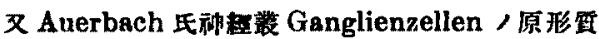

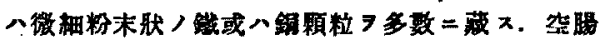

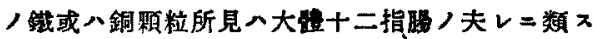

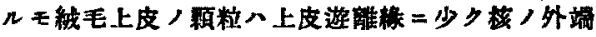

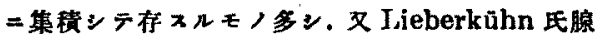

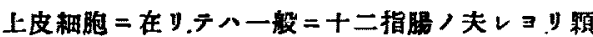
䊉多ク又澉梱ニシテ主トシテ湅胞基底部二存ス，

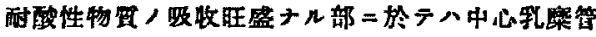

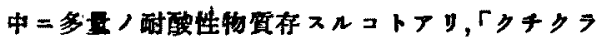

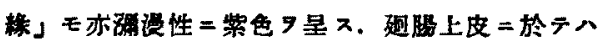

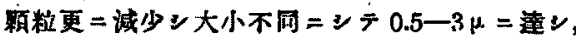

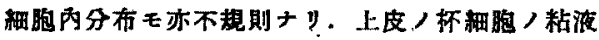

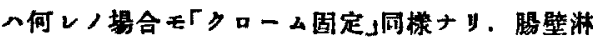
巴特置 等湅胞 =比ン琙, 銅顆粒共 $=$ 多数 $=$ 存 $\mathrm{z} 、$ Baryt

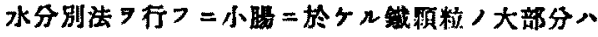
是色性 $\nabla$ 失フモ銅顆粒八可成抵抗强ン，十二指睛

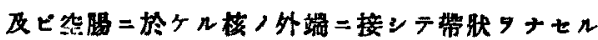

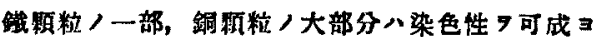

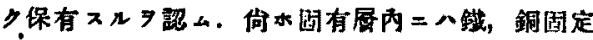

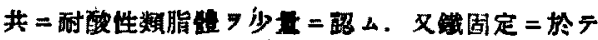

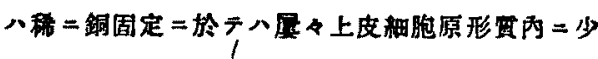

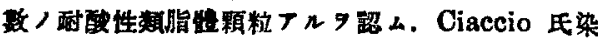

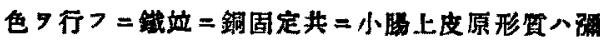

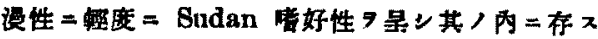

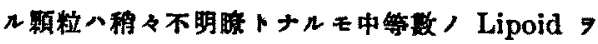
含有スルモン多ン．首钯 Baryt水分別 $=7$ 染色性 》保有入几顆粒八篮色二溜染入。

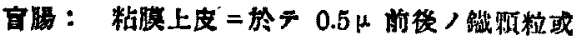

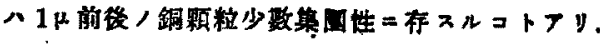

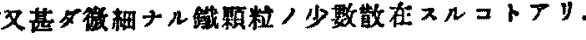

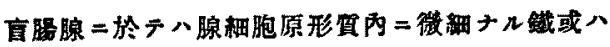
铜顆粒 7 少数認、得. Baryt 水分別 =於元鐵，銅 固定共二粘膜上皮ノ顆粧中=八抵抗强 $\neq モ /$ 稀 存スルモ多夕八耐酸性 9 失フ 7 見ル。 Ciaccio 氏 染色二於テハ $0.5 \mu$ 以上ノ顆粒八橙黄色=染色 ルョ認ムルモ微䋧顆粒八不明蹽ナり。

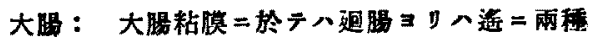

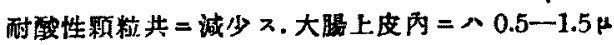

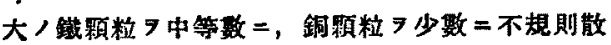

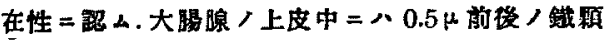

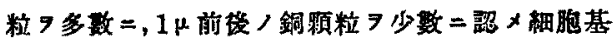

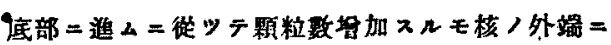

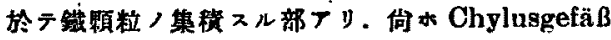

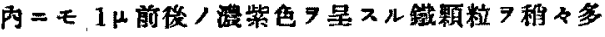

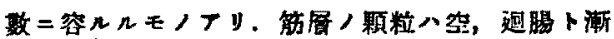

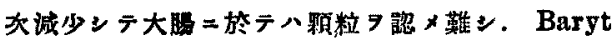

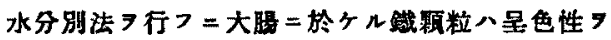
消失ン易ク，銅颗粓ノ夫レハ稍々抵抗强ンCiaccio 氏染色 7 行フ二上皮細胞垓ノ外端二接 $几$ 鐵颗粓 八可成强》橙蒙色二染色廿レ，核ノ上部ョり離レ

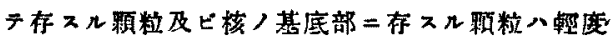

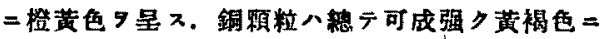
湤染せ几。

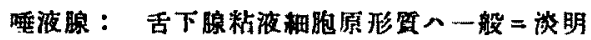

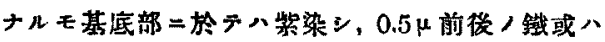

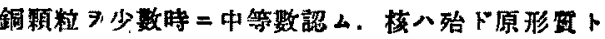

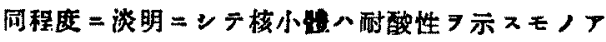

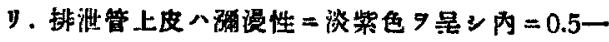
$2 \mu$ 大ノ践顆粒 $1-5 \mu$ 大八銅顆粒 /多数二存 $ス n$

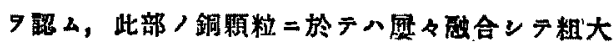

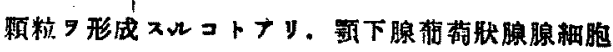

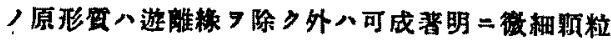

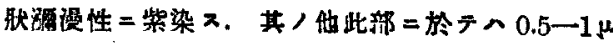
大ノ钱或八銅顆粒

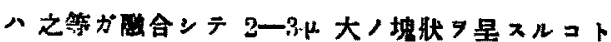

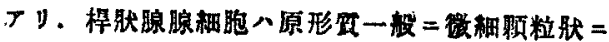


稍々著明二紫色 9 呆ン他 $/$ 性狀八前者二同シ。排

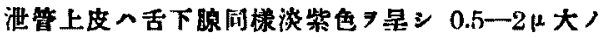

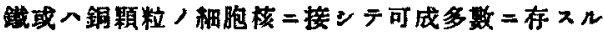

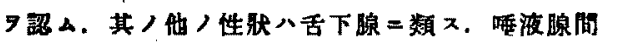
算秥締織 ニ於ケルト同㥞ナリ. Baryt 水分別 筐上皮/顆粒八的，銅固定共二可成／抵抗 8 有 ルモ其八他八顆粒八殆ド消失 ス。Ciaccio 氏染色

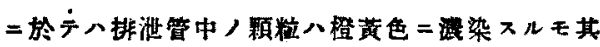

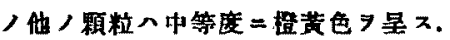

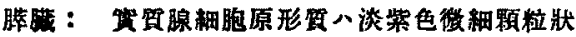

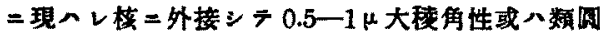

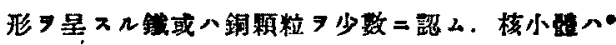

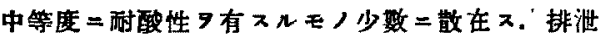

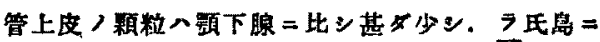

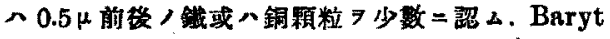

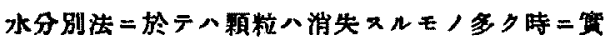

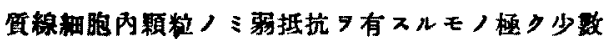
二存ス. Ciaccio 氏染色二於テへ顆粒ハ一般二淡 橙黄色 7 是 $\pi$ 。

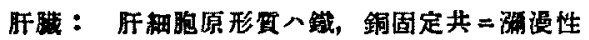

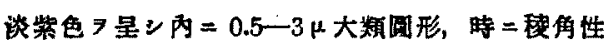

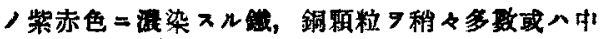
等数 =有スルモノフリ．肝腈二於テ八消化，時期

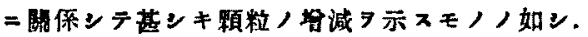

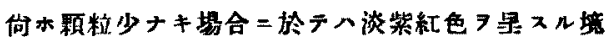

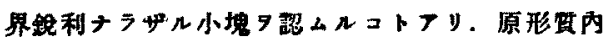

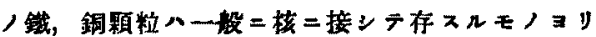

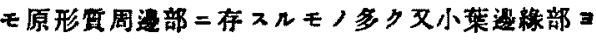
リハ中心部二多キモ，灀漫性ナル場合多ン、及稀

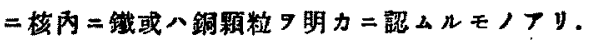

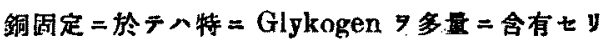

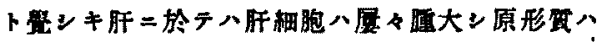

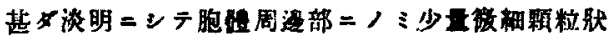

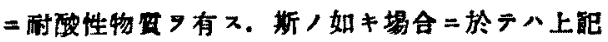

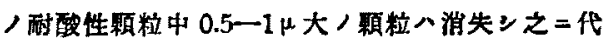
$7 n=2-5 \mu$ 大類国形ノ顆粒中等数 $=$ 出現 $\pi$,

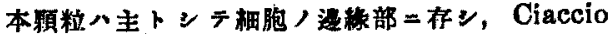

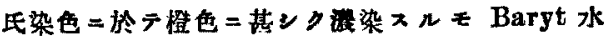

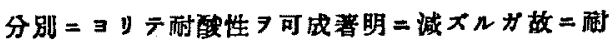
酸性顆粒 ニシテ大量，Lipoid 7 含有スルモノナ

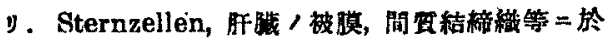

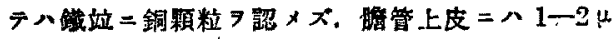
，耐酸性顆粒 7 少数 $=$ 詔 4. Baryt 水分別法 7 行

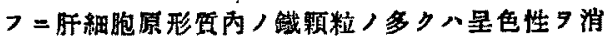

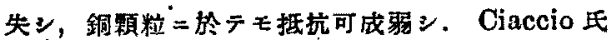
染色二於テ八肝細歇原形两内顆粒八鐵，銅固定共 = Sudan 啫好性可成强ク珠二粗大ナル銅顆粒二 於其八性著》。

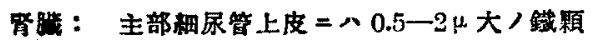
粒 7 确漫性 =可成多数＝認ムルモ時トンテ上皮基

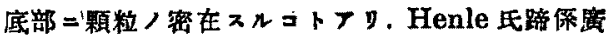

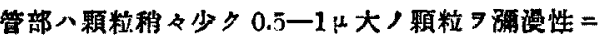

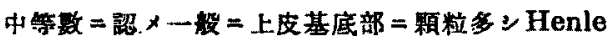

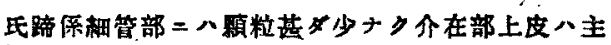
部細尿管 ヨy.㑤二顆粒数多キノミナルフ以テ「タ ローム固定」二於ケルガ如ク颗䊉ノ密度、リ本部

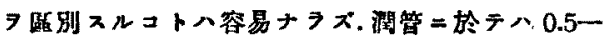

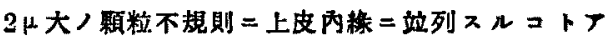

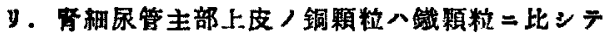

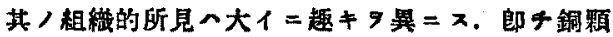

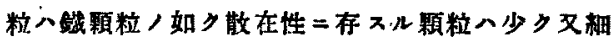

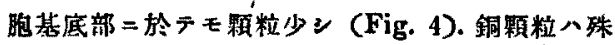
二主部湅尿管上皮二於テ刷子格二多数=存ン，元

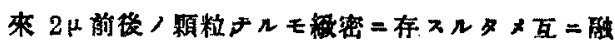
合ンテ刷子悢二於テ著明ナル带狀局

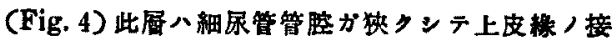

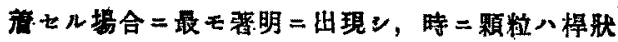

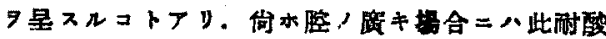

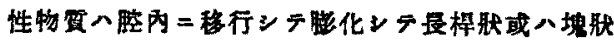

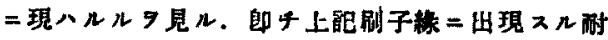
酸性物面八分泌物ノ一成分 ナナンテ尿二移行スル

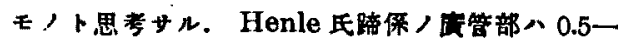
$2 \mu$ 大诨狀或八塊狀 / 銅頛粒 


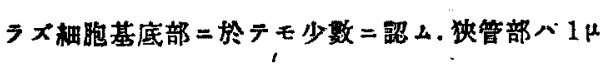
前㷋 八銅顆粒 7 中等數

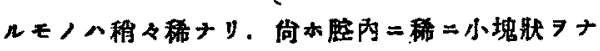
七几酎酸性物算 7 見儿，腎稩尿管上皮ノ粗大ナル 銅顆粒八一般二其ノ基筫租糙ナルモノ多多往々空 胞形成

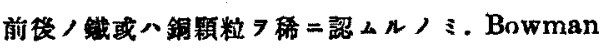

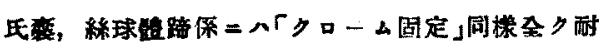

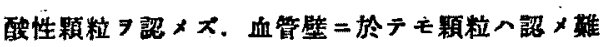

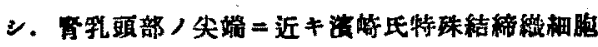

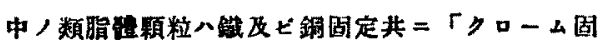
它」八坦合卜略求同㥞ナy．Baryt水分別法７行

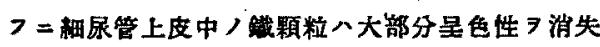

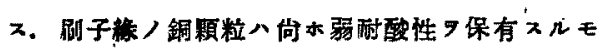

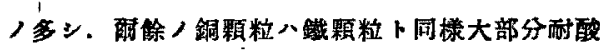

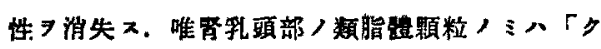

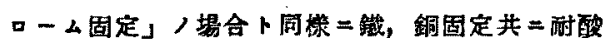

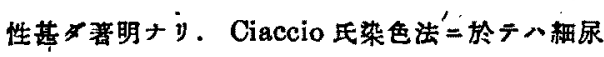
管上皮，Baryt 我分别二於テ是色性》滑失七几

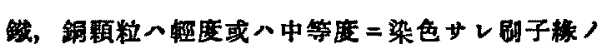

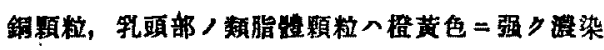
z.

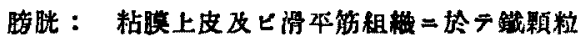

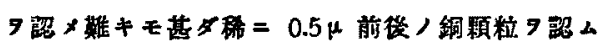

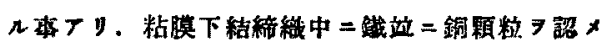
ズ. 筇轿維間=少政 Mastzellen 存ン其ノ所見

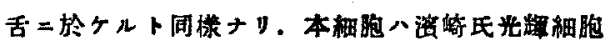

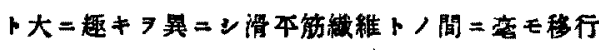

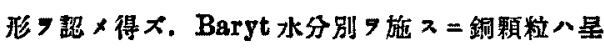
色性 7 失フ. Ciaccio 氏染色二於テ此部 銅顆粒 八不明璄ナリ。

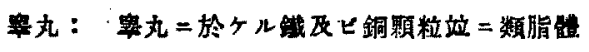
顆粒所見へ「クローム固定」三於ケル場合卜略林间

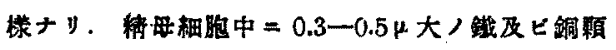
粒存スルモ淡售 7 号ン「クローム固定」於ケル ガ如ク明䀧ナラズ、精上皮ノ基底部 Sertoli 氏細

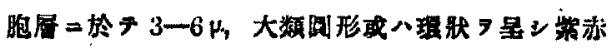

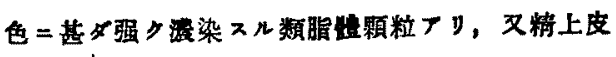

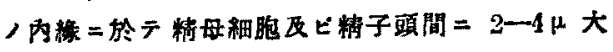

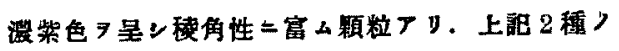
粗大顆粒ハ「クローム固定」二於ヶル堤合ト全ク同

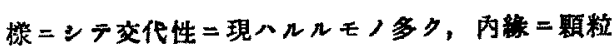
多キ塄合八精子形成旺ンニンテ，精子人管腔中心 部=集合ンテ存ス（Fig.6).何水稀:細精管肉，

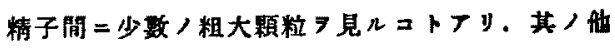

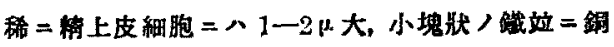

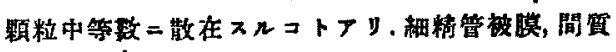

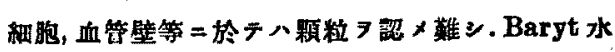

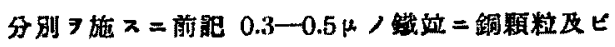
細精管中， $1-2 \mu$ 大，顆粒八全夕是色性 7 消失

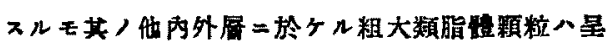

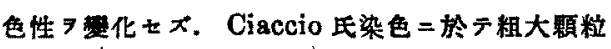
八縝テ高度，Sudan暏好性 7 現ヘン特二䅌上皮 基底部ノ粗大頼粒二於テ著ン。

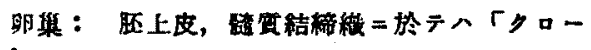
么固定」同栐耐酸性顆粒 9 㖕 $\times$.

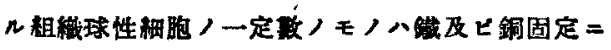

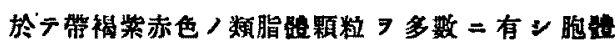

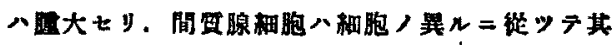
ノ差瑟シキモ「クローム固定」=比シテ稳々多数

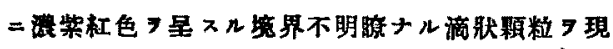

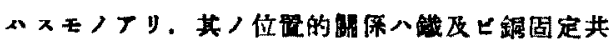

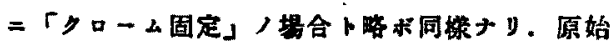

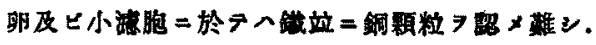
Graafscher Follikel / 䉥胞上皮 $=\propto 0.5-1 \mu$ 大

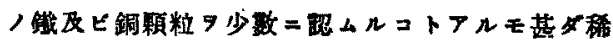
テリ、黄體ノ「ルテイン」細胞=於テハ「タローム

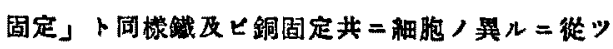

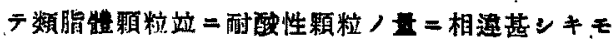

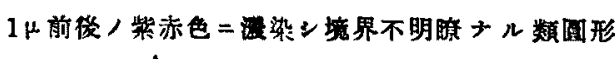

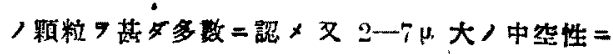
環幜

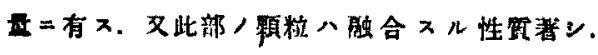

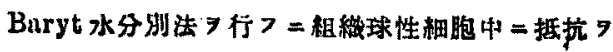




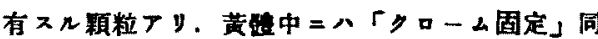
梾鐵及ビ銅固定共二抵抗强キ顆䊉 7 可成多数二諰 ムルモ銅固定二於テ珠=多乡。其！他ノ顆粒八鐵 固定二於テハ殆ド全少酎酸性习消失スルモ銅固定

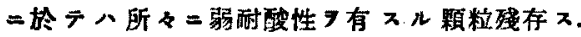

Ciaccio 氏染色二於テ八践及ヒ銅顆粒共二可成湍

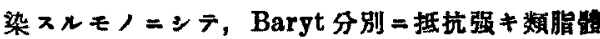

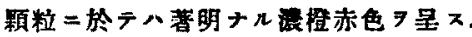

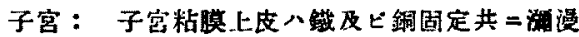

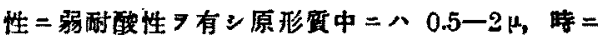

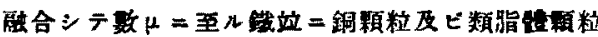

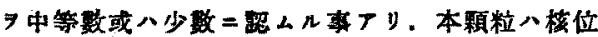

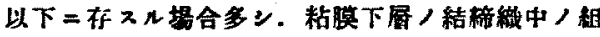

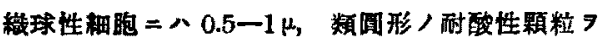

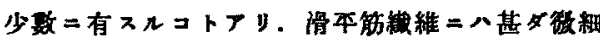

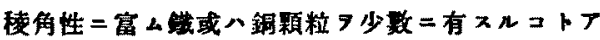

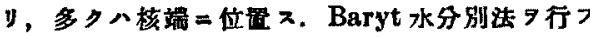

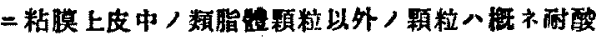
性 7 失フ. Ciaccio 氏染色 7 行

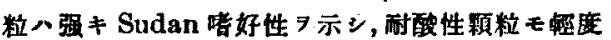
= Sudan書好性 7 示 $\pi$.

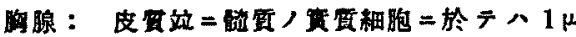

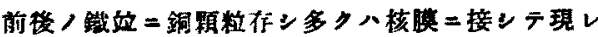

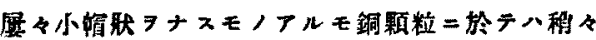

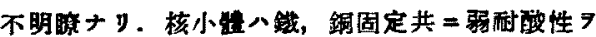
現ヘン紫赤色二染色サルルモノアリ。肥大七ル絧

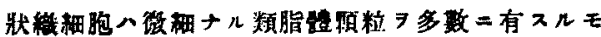
イフリ：Baryt 水分別=於テ上記耐酸珄顆粒及ビ

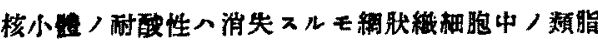

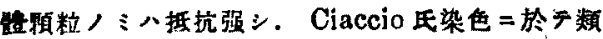

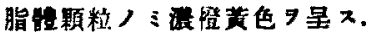

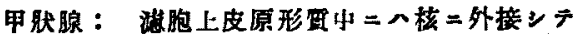

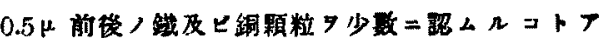

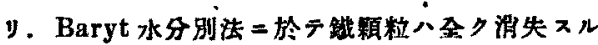
モ铜顆粒中=八弱耐酸性

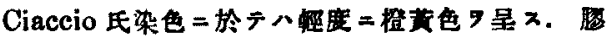

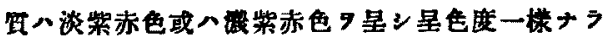

x.

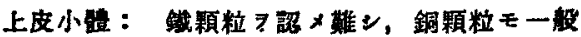

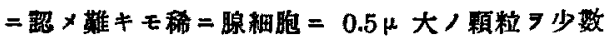

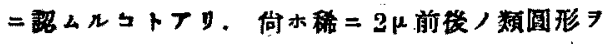

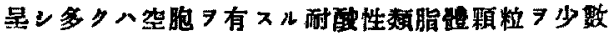
ニ見ルコトナリ. 本顆䉼ハBaryt水分別二對ンテ 抵抗 7 有シ Ciaccio 氏染焦二橙蒙色二染色サ几。

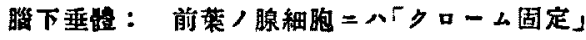

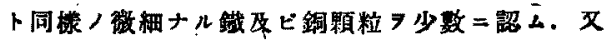

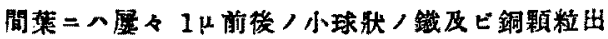

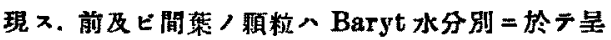
色性 $习$ 消失ン Ciaccio 氏染色二於テ不明䁻ナリ。

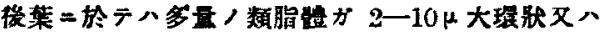

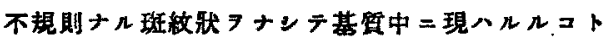

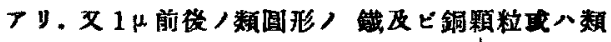

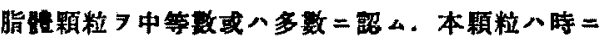
掘合ンテ小塊爿

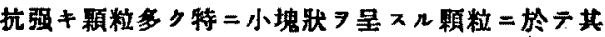

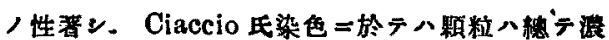
橙䔩色 7 呈 $ᄌ$ 。

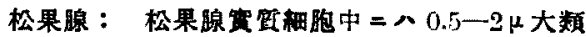

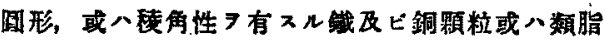

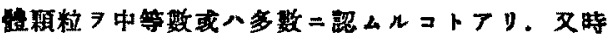

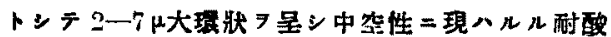

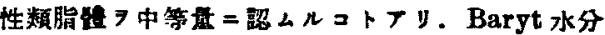

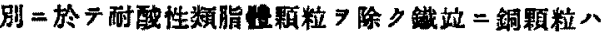
抵抗弱ン。 Ciaccio 氏染色=於テ八耐酸性颣脂的

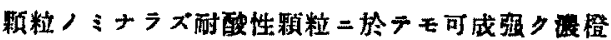
愄色星

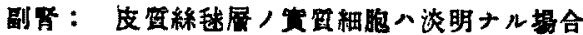

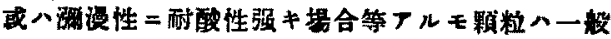

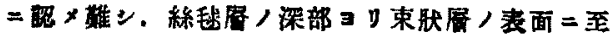

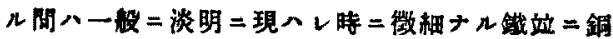

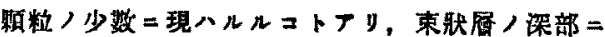

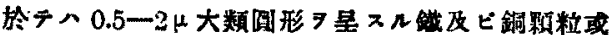

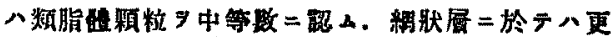

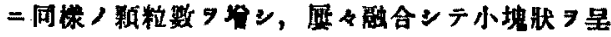




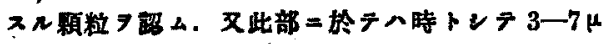

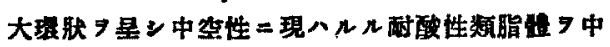

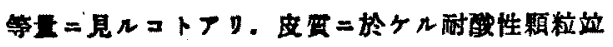

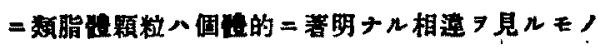

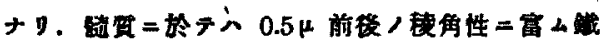

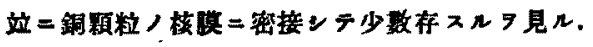
Baryt 水分明法二テ東狀局下部及と絧就居二於ヶ

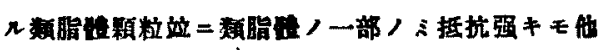
八㱠下耐酸性 7 消失 $邓$. Ciạccio 氏染色二於テ八

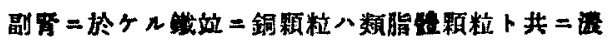
染廿n.

\section{總括考揬}

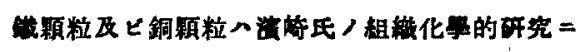

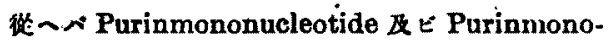
nucleoside 7 主成分トナスモノニンテ践顆粒八前 者

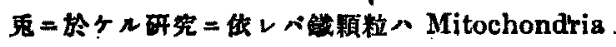

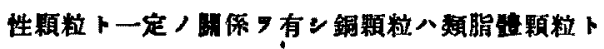

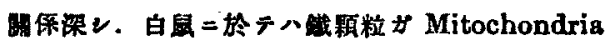

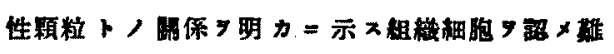

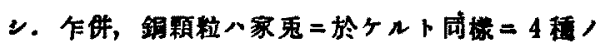

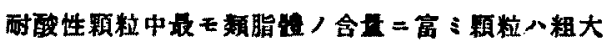

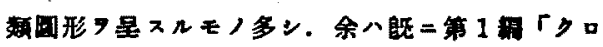

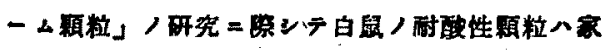

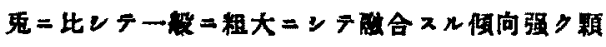

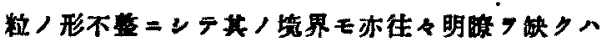
Lipoid /合昰多キタメナルコトラ指摘七刀，正

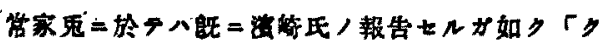

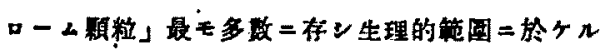

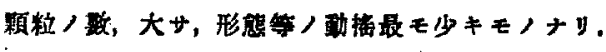

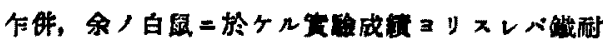

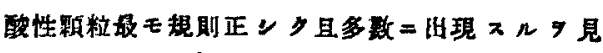

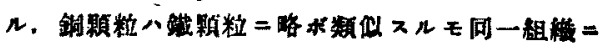

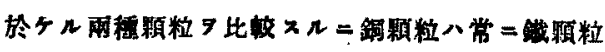

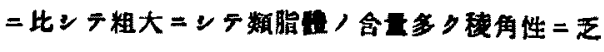

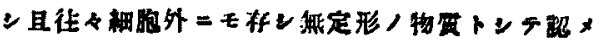

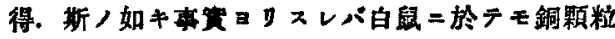

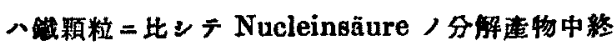

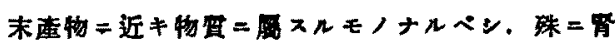

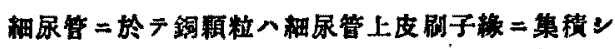

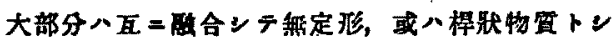

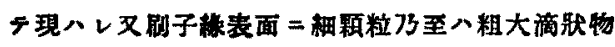

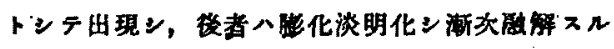

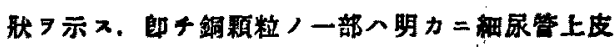

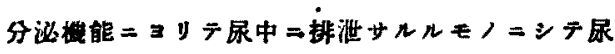

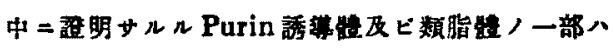

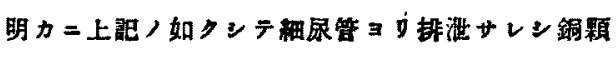
䊉二由來スルモノナルコトラ知几。

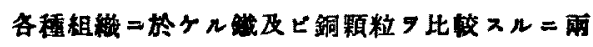

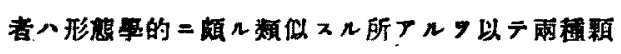

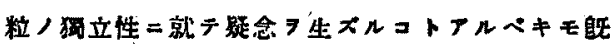

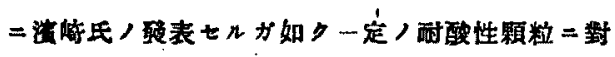

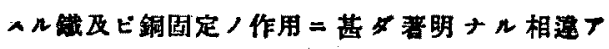

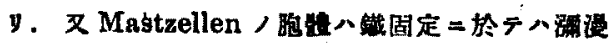

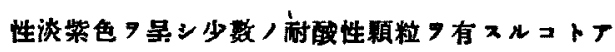

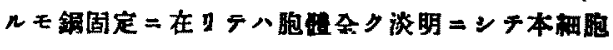

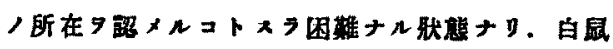

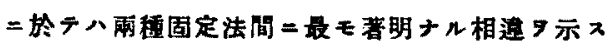

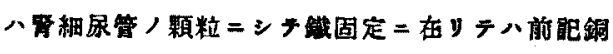

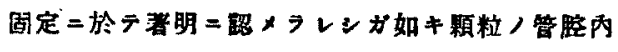

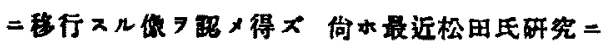

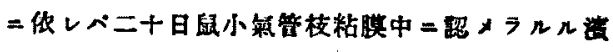

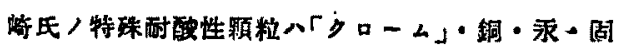

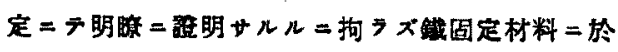
テハ全ク酎酸性す現ハサズト云フ。

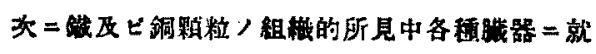

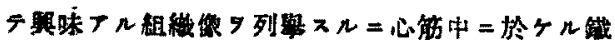

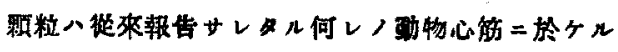

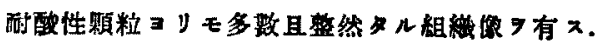
「クローム固定」法二准りテハ淋巴腺腺䢸㵶，殊二

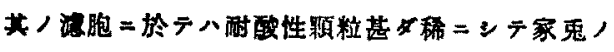

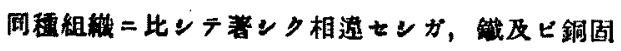

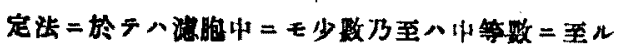




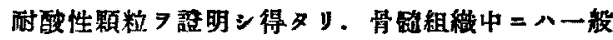
二家鬼，白鼠习通ジテ耐醊性颗粒习缺クモノナル

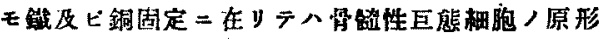

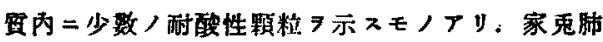

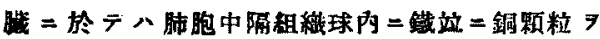

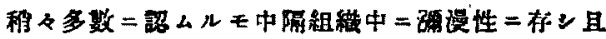

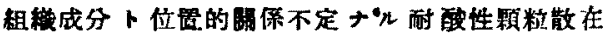
スタメ粗機球中，顆稤特二寒明二現ハルルガ如 キコトナン。然ル＝白鼠肺跑中隔中二八确漫性二

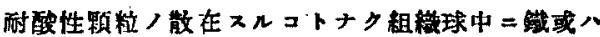

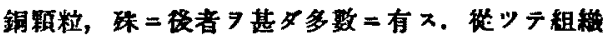

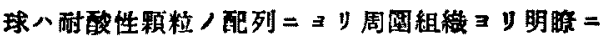

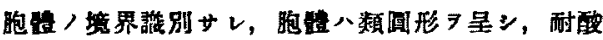

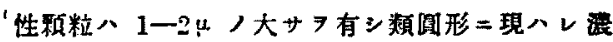

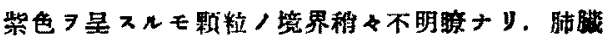

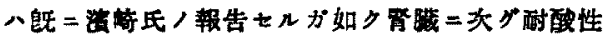

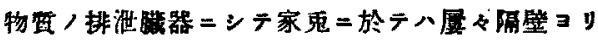

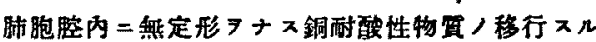

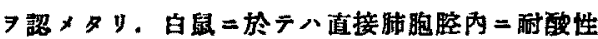

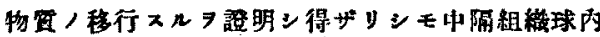

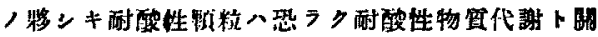

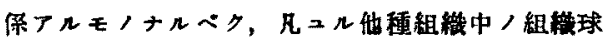

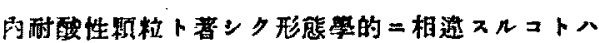
大二注目スベキ所見ナリ。

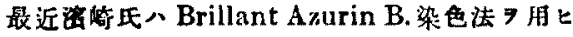
テ表皮內二八多是，Histon 存” Keratohyalin

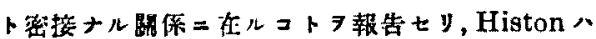

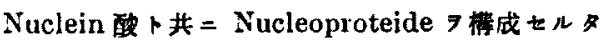

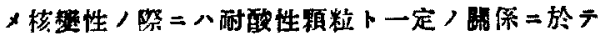
但現スルラ常トスルモ，表皮二於ケルガ如ク生理 的二存スル Histon 八必ズンモ耐酸性颗粒

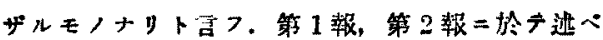
タルガ如ク府年上皮二於テハ「クローム」及ビ良・

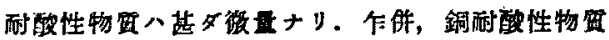
八比教的多量二存ン珠二角化展深部二八带狀すナ

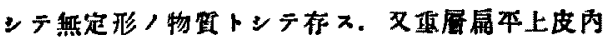

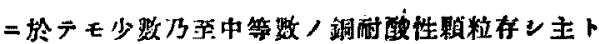

ンテ校端二位霞ンテ时現

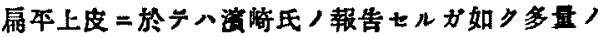
Histon 證明サルルモノナルガ此部二於テ八銅耐

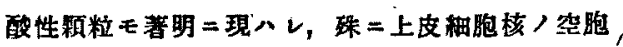

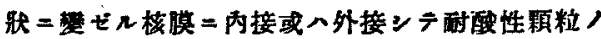

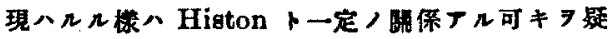

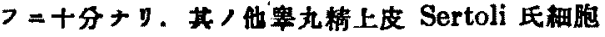

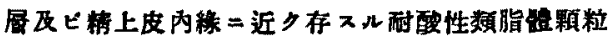

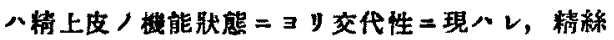

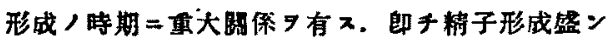
ニンテ精子八其 /尾部知精管中心部二集合センメ

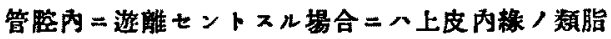
颗糡多致二出现シ，基底部厂颗粒少ン，反之精 子形成媎明ナシザル熶合二八Sertoli 氏絓胞屏，

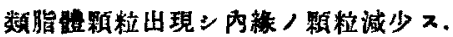

\section{結 論}

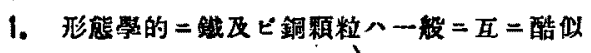

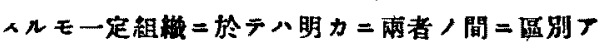

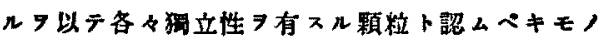
ナข.

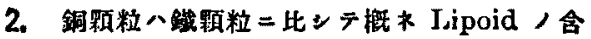

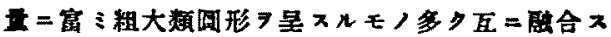
几佩向强上。

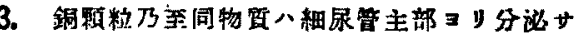
レ展成分ノ一部フナスモノナリ。

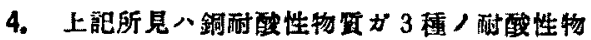

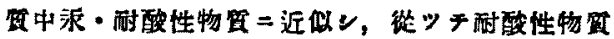

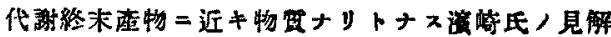
=合效 2 .

5. 白鼠肺胞中隔丙/組維球八銅頪粒 7 多数二

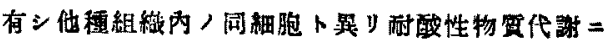

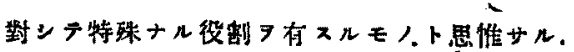

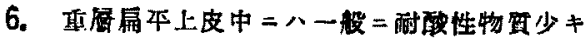

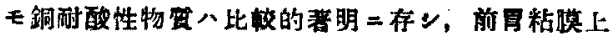

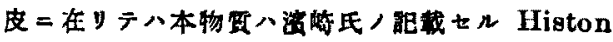

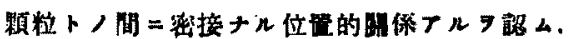




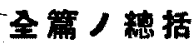

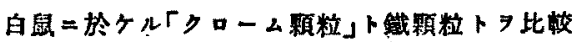
$ス ル=$, 第 1 報二於テ述ベシ如ク白鼠ノ「クロー ん顆䊉」八Nucleinsäure／外 =比较的多县，水 漂性ナル Mononucleotide そビ Mononucleoside

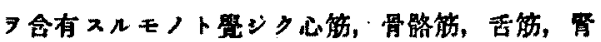

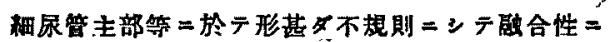

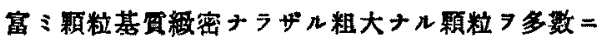

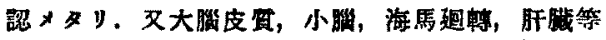

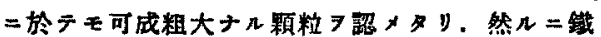

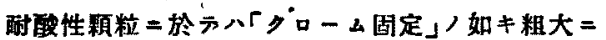

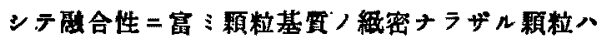
甚ダ少ン，䬦千心筋 (Fig，1)，骨路筇，舌，带稩 尿管主部 (Fig.'3) 然三於テモ䎦粒八徽湅ナルモ

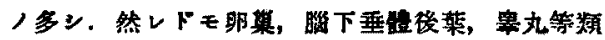

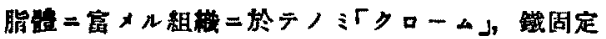

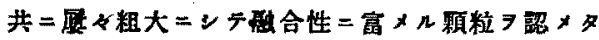

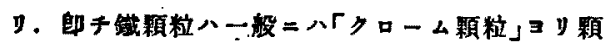
粒微湅 ニシテ壁合性二乏ンク從ッテ顆粒二大小不

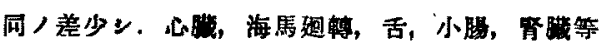

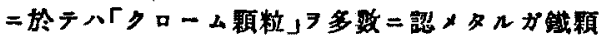

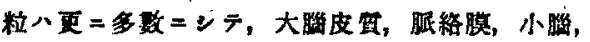

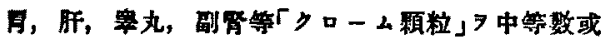

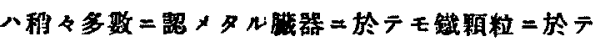

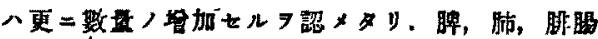

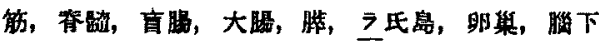
乗能，松果腺等二在りテハ少数或八タ甚タ少數，

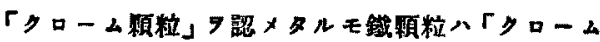

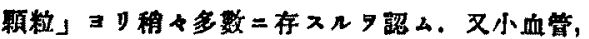

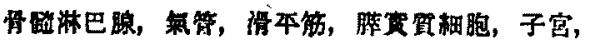

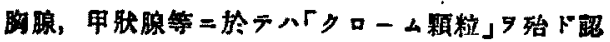

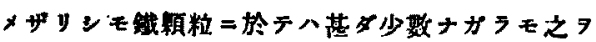

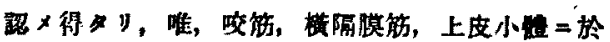

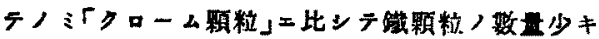

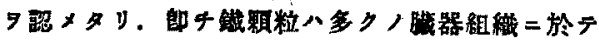

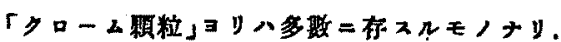

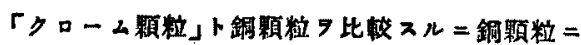

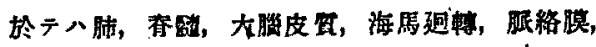

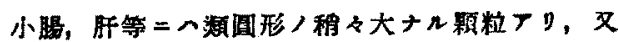

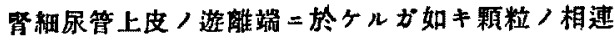
リテ大ナル样狀 7 虽スルナリ，又舌，心筋，骨路 筋等二於テハMyelin 形 7 呈スル粗大ナル顆䊀現

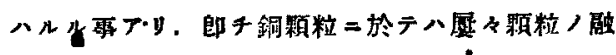
合シテ大トナルもノフルモ「クローム顆粒」ヨリハ 腈合性少ン，而ンテ銅顆粒二於テ八顆粒骶合ス几 モ顆粒基筑粗ナラスンテ顆粒ノ境界モ「クロー ム」, 粗大顆粒 ヨリ八鏵利ナリ. 文顆粒ノ形モ 「クローム」ノンレコリ规則正ンギ常トス。脾,

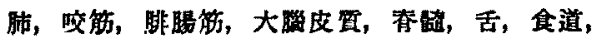

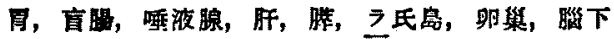

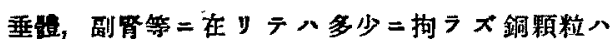
「クローム顆粒」ヨり数多ク．小血管，淋巴腺，策

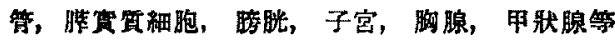

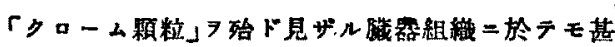
タ少数ナガ

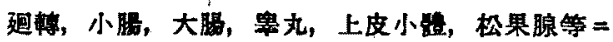

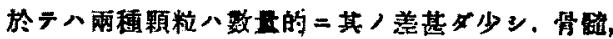

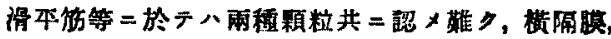

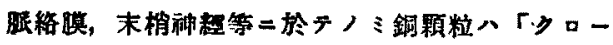
么顆粒」ヨy程々娍少入。

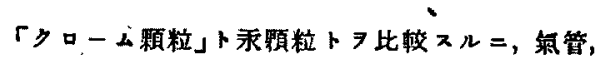

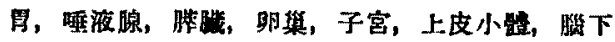

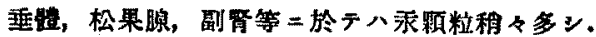

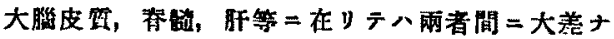

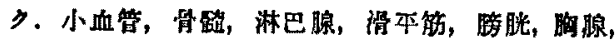

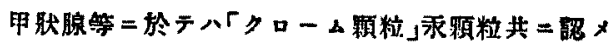

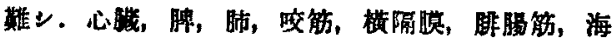

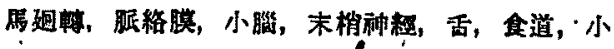

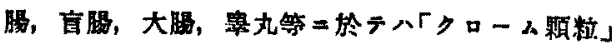
二比ンテ乘制粒つ数科々少ン。

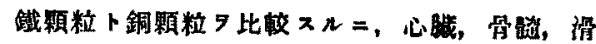

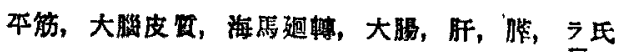

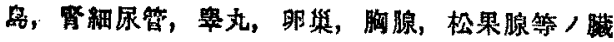
器 $=$ 於テ八践顆粒八銅顆粒 $コ$ リ一般二多ン.小血 


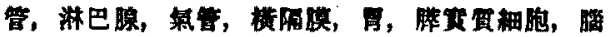

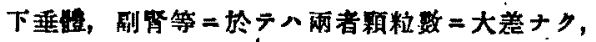

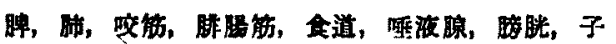

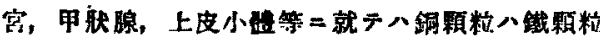

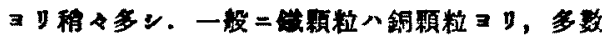

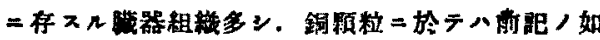

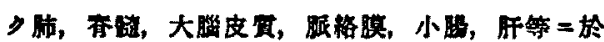

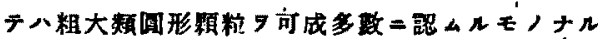

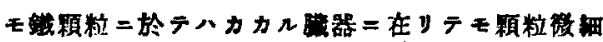

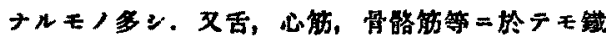

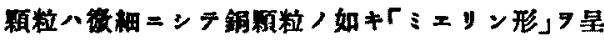

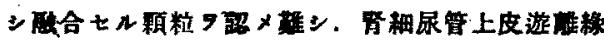

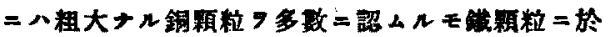

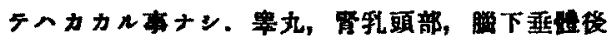

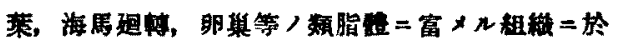

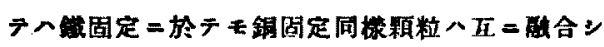

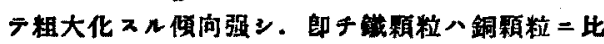

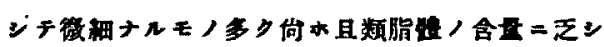

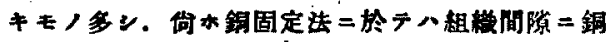

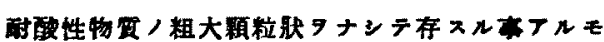

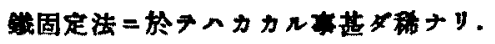

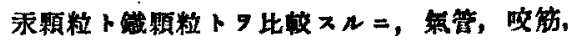

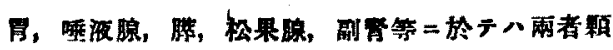

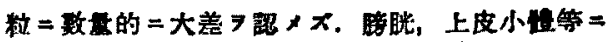

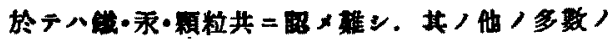

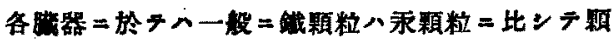

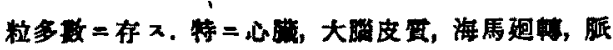

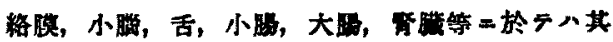

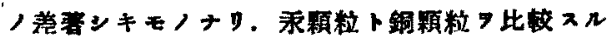

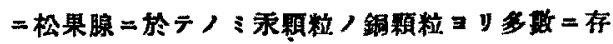

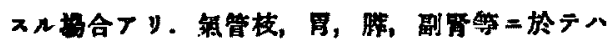

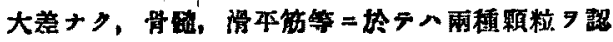
メ萑ン。其八他ノ各䑏器二於テ八銅頪粒ハ一股二

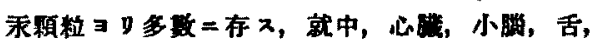

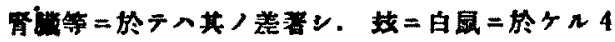

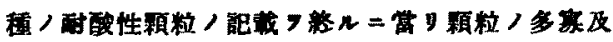

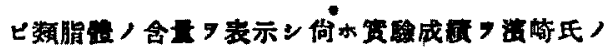

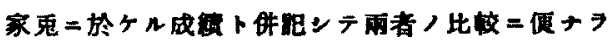
$2 \times 2 y$.

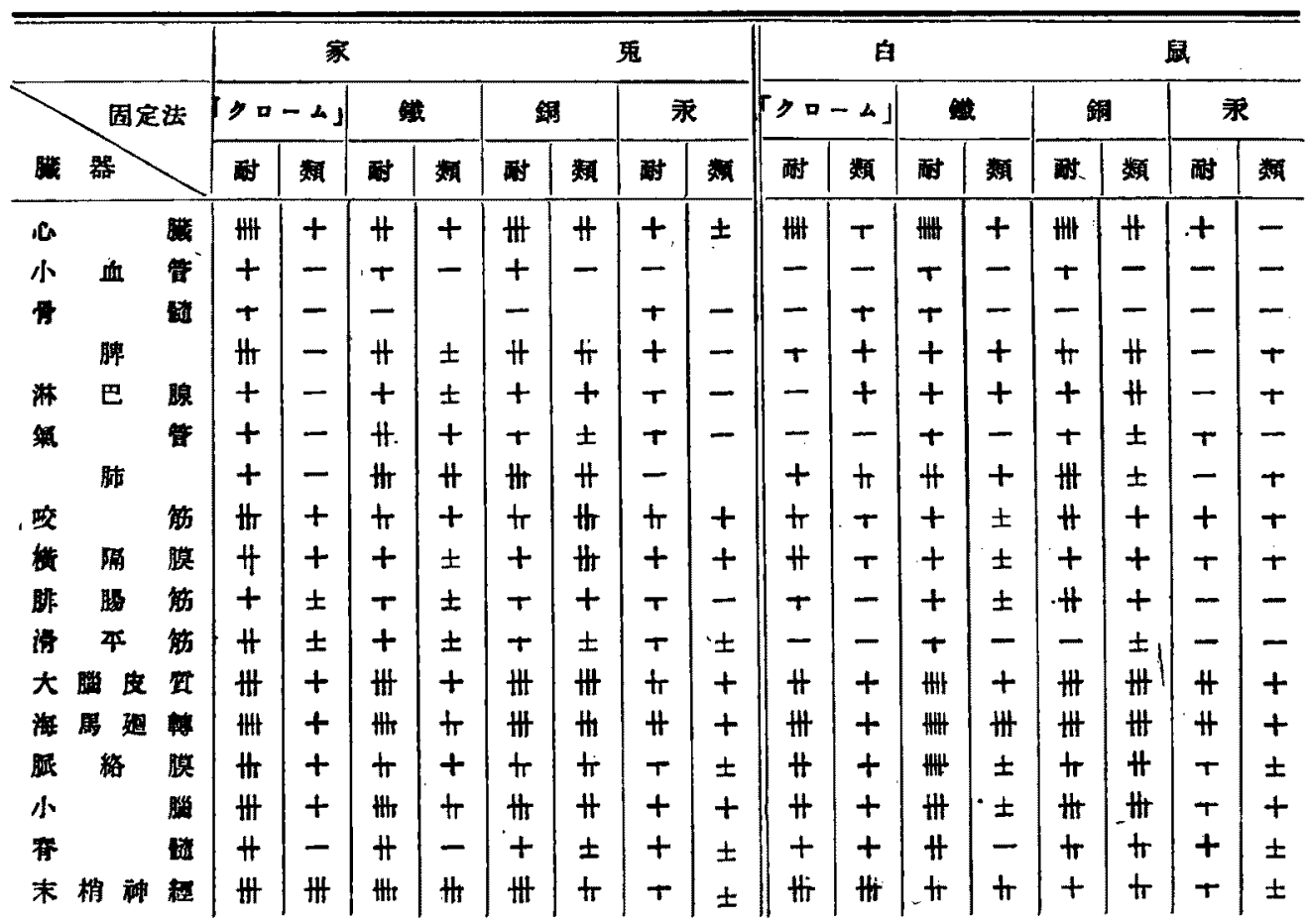




\begin{tabular}{|c|c|c|c|c|c|c|c|c|c|c|c|c|c|c|c|c|c|c|}
\hline & & , & \multicolumn{4}{|c|}{ 家 } & \multicolumn{4}{|c|}{ 鬼 } & \multicolumn{4}{|c|}{ 白 } & \multicolumn{4}{|c|}{ 鼠 } \\
\hline \multirow{2}{*}{\multicolumn{3}{|c|}{ 巷翼 }} & \multicolumn{2}{|c|}{ r $\Rightarrow 0-4 J$} & \multicolumn{2}{|c|}{ et } & \multicolumn{2}{|c|}{ 銅 } & \multicolumn{2}{|c|}{ 湬 } & \multicolumn{2}{|c|}{$|r| a-4 J$} & \multicolumn{2}{|c|}{ 鐵 } & \multicolumn{2}{|c|}{ 銅 } & \multicolumn{2}{|c|}{ 争 } \\
\hline & & & 酎 & 颣 & 跱 & 颣 & 酎 & 類 & 酎 & 效 & 耐 & 数 & 耐 & 頪 & 酸 & 颣 & 跱 & 数 \\
\hline & 舌 & & H & $\hbar$ & H & + & H & H & \# & + & $H$ & + & 册 & \pm & ff & Ht & + & $T$ \\
\hline & & 道 & + & - & + & \pm & + & \pm & tr & \pm & + & - & + & - & tr & \pm & $T$ & - \\
\hline & A & & + & - & th & \pm & tr & t & $T$ & - & $t$ & - & $\#$ & \pm & H & \pm & H & $T$ \\
\hline 小 & & 晤 & HHt & $\#$ & \# & Ht & H & \# & $T$ & \pm & Ht & H & 册 & \# & $\#$ & 林 & + & \pm \\
\hline 目 & & $\mathrm{H}$ & $\#$ & + & + & \pm & + & + & - & & $T$ & - & tr & $T$ & + & tr & - & - \\
\hline 太 & & A & - & & $t$ & + & Ht & th & - & & + & $T$ & 册 & \pm & + & H: & $r$ & - \\
\hline 滦 & 做 & 腺 & + & - & + & \pm & + & + & $T$ & - & + & $T$ & $\#$ & $T$ & Ht & + & H & \pm \\
\hline & 肝 & & H & \pm & $H_{1}$ & \pm & H & H & H & + & tr & $H$ & 米 & + & $\#$ & $\#$ & $t$ & \pm \\
\hline 搭 & ， 睆 & & + & - & $T$ & - & + & + & - & & - & - & + & - & + & \pm & + & - \\
\hline & $1 \geq$ & 岛 & + & - & $r$ & - & + & + & $T$ & - & $T$ & - & $\pi$ & - & + & \pm & + & - \\
\hline$\pi$ & & 葓 & 册 & - & HAl & - & Ht & Ht & \# & + & H4 & $\pi$ & 册 & H & H\# & Ht & $t$ & + \\
\hline 酸 & & 垷 & + & - & $T$ & - & + & \pm & $T$ & - & - & - & - & - & $T$ & - & - & - \\
\hline 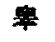 & & 丸 & $H$ & \pm & + & \pm & $T$ & \pm & $T$ & \pm & $H$ & 曲 & H & Hr & H & H & $T$ & Hit \\
\hline 郋 & ' & & H & + & + & \pm & $t$ & + & + & + & $\mathbf{T}$ & H & $\pi$ & $\#$ & $t r$ & H & + & tr. \\
\hline 子 & & 宫 & + & - & + & - & - & & + & - & - & - & + & + & tr & + & $T$ & - \\
\hline 腊 & & 瑔 & $\#$ & - & $t$ & - & $T$ & - & + & - & - & + & + & + & $T$ & + & - & $T$ \\
\hline 甲 & 狀 & 泉 & + & - & $T$ & - & + & - & $T$ & - & - & - & $t$ & - & + & $T$ & - & - \\
\hline 上 & 皮 小 & 돌 & + & - & - & $\cdot$ & - & & + & - & $T$ & - & - & - & $T$ & - & - & - \\
\hline 腆 & 下垂 & 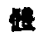 & + & - & $T$ & - & $T$ & - & + & - & $T^{\prime}$ & $\pi$ & $t$ & $\pi$ & $t$ & 卅 & + & $\pi$ \\
\hline & 果 & 䠌 & $T$ & - & - & & + & - & + & - & $T$ & + & + & + & + & + & + & - \\
\hline 晋 & & 霄 & $H$ & t & th & + & + & + & $H$ & $t$ & $\pi$ & Ht & $H$ & $\#$ & $H$ & 舟 & $\#$ & H \\
\hline
\end{tabular}

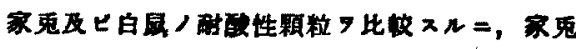

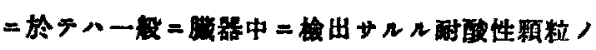

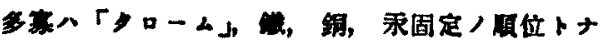

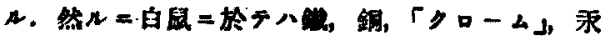
固定ノ间ナy，而ンテ之等顆籹中生理的狀盟二於

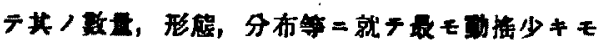

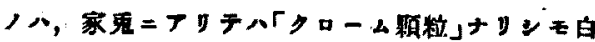

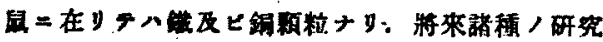

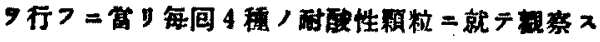

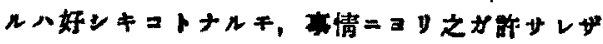

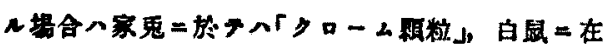

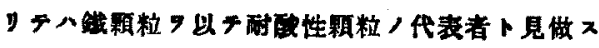
テキナリ。

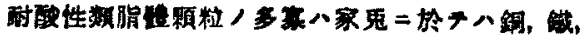

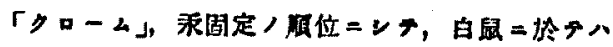

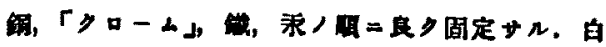

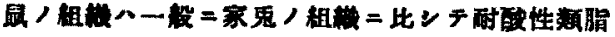

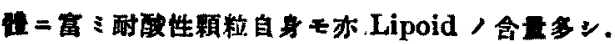

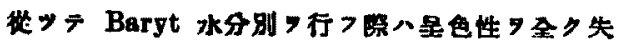

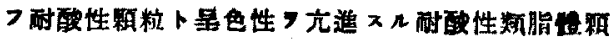

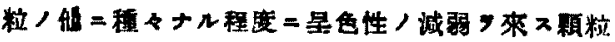

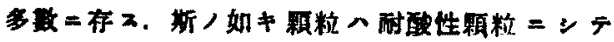

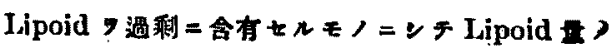

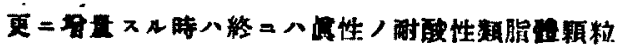

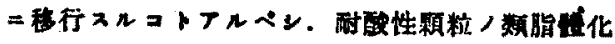

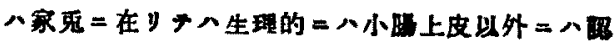

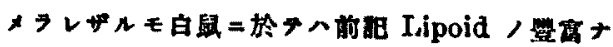

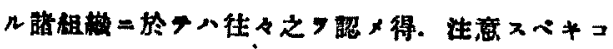

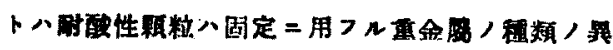

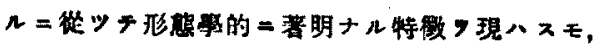

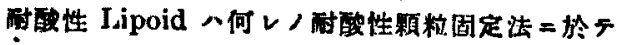

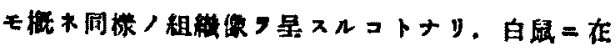




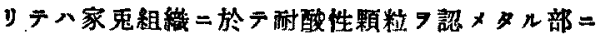

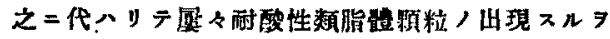

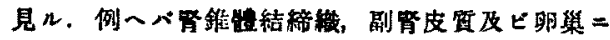

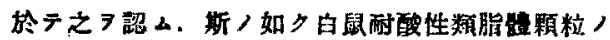

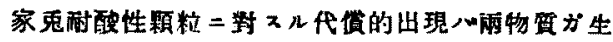
物學的二密接ナル雕係 $\mathrm{g}$ 有 ルモノナルベン，挏末家鬼二在リテハCiaccio 氏 固定法=元政酸性顆粓／固定サルルコトナカリン

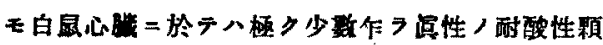
粒固定せルルヌ認メタリ。コレ恐ラク白闵二在り

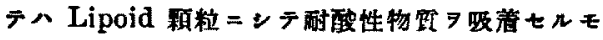
ノ存スルタメナルベシ。矿酸性類脂鼠顆粒八斯，

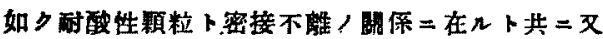
一方從來部載サレタ几通常ノ Lipoid ト密接ナル

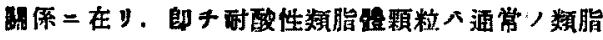
链卜耐酸性顆粒ノ中閒型卜考へ得几モノンシテ脂 助代謝系卜核酸代謝朵卜习连結スル例鎮 (Seiten-

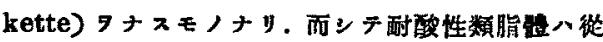

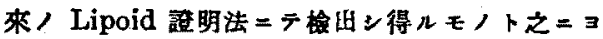
リテ湌出ン得ザルモノフリ。㷋ツテー般=Ciaccio

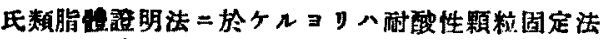

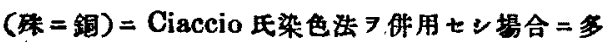

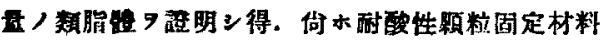
= Baryt 水分别 9 行一nモ＝在りテ八耐酸性

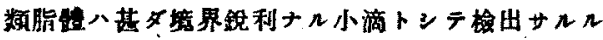

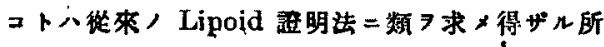
$ナ リ$.

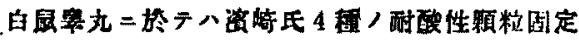

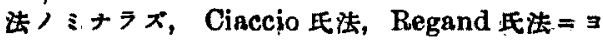

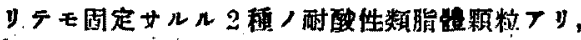

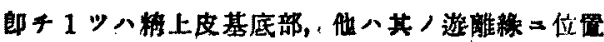

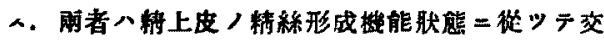
代性二現ハレ注目スベキ Lipoidナり，霓丸内，

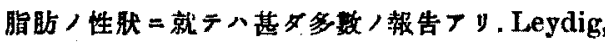

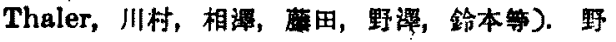
㵏八大黑鼠八精子形成波 77 期二别千各期=於夕 凡脂助顆粒二就テ相案ン，精子形成初期二於テハ
椅上皮周息部二粗大頼粒 7 見，中心部二顆粒少ク， 精子ガ中心部二策合ン遊龍セントスル期二八周

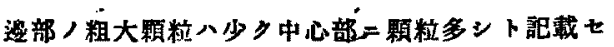

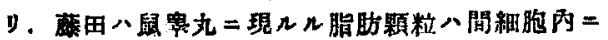

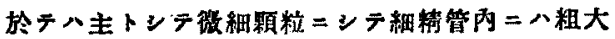

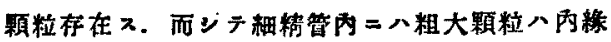
及ピ周济部二存ン，而シテ細精管ノ中心部二粗太

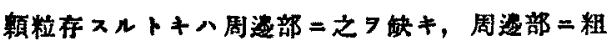
大顆䊉存 ス几特八中心部=之ョ蚗クト言へリ。 Plato, Ebner, 霜田等八番丸內脂肪顆粒八細䊑管

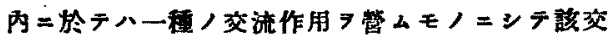

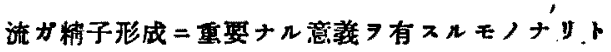

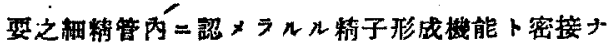

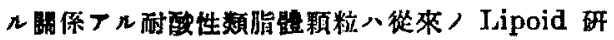

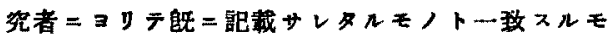

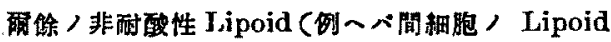

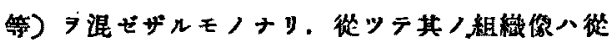

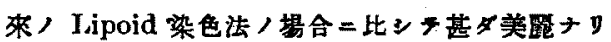
(Fig. 6).

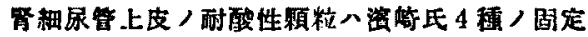

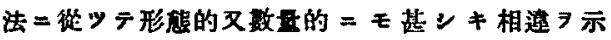

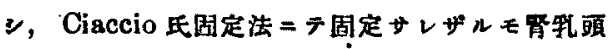

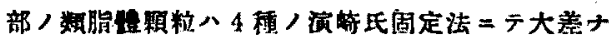
キノミナラズ Ciaccio 氏法, Regand 氏法ニテモ 略ボ同棈二固定サル。

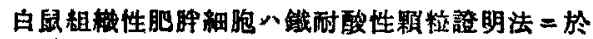
テノミ原形社內二微細ナル顆粒 7 少数二現ハスュ トフリ。乍作，本細胞八啫鼠基性特䛈顆粒八海绮

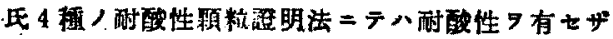

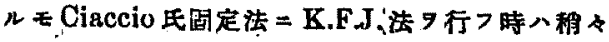

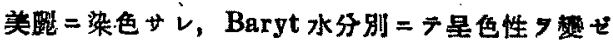

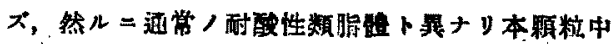
ニ八Lipoid，證明ン颉ン。的肥㭌緗胞特殊顆

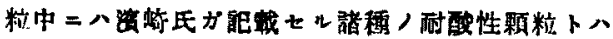

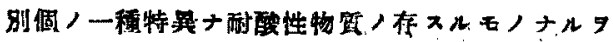
知几。

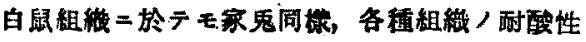


顆粒八大部分外来的耐酸珄賴粒 (expgene eäure-

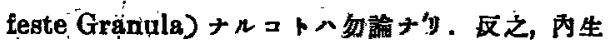
的耐飘性頼粒 (endogene säurefeste Granula) 八甚ダ少数ナルモ，本顆䊉ノ研究八一般耐酸性顆 粒八由來或八生物悬的意義二就テ重要ナル論㨜

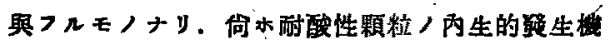

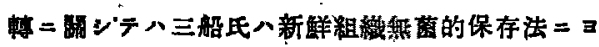

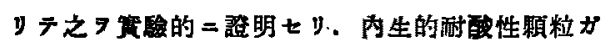

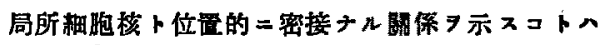

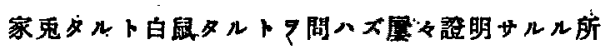
ナク.「クローム」耐酸性顆精 =在りテハ令道下部

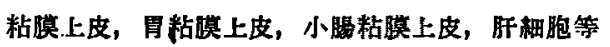

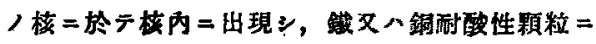

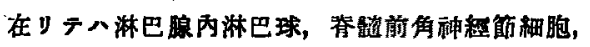
舌粘膜基底細胞，前罗粘膜上皮，肝細胞等 $=$ 於テ

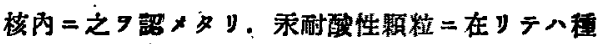
種 八腺細胞核內 $=$ 壮現七リ。其ノ他核膜=外接ン

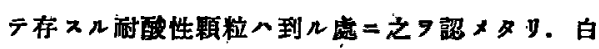

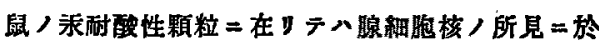

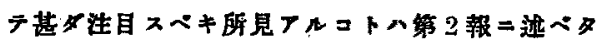

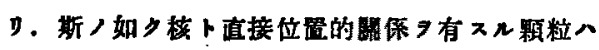
單ナ几核蛋白代裤物トンテ現へ几場合ト一定，

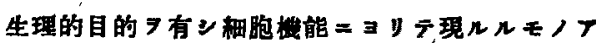

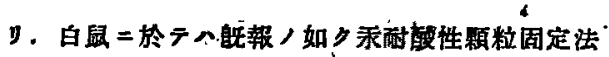

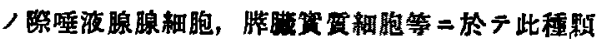
粒 證明スルコトラ得ペン。

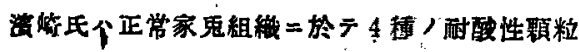

文

1) Ebner, Arch. fūr mikr., Anat., Bd. 31,

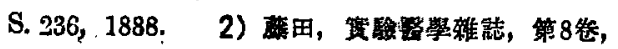

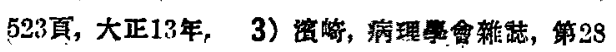

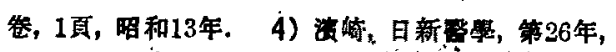

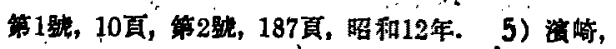
日新紐學，第26年，第4號，580面，昭和12年4月。

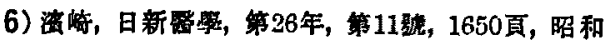

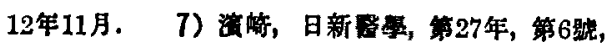
914而，昭和13年6月，8）川村，日新祭學，第7年，

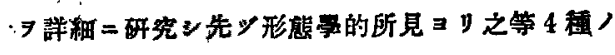

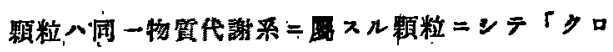
一ム」耐酸性制粒八最主級核蛋白ニンテ鐵及ビ 銅顆粒之二资半，我顆粒八終末座物ナ儿可キコト

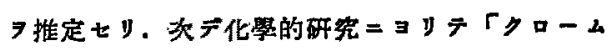

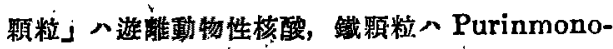
nuclotide 銅鹤䊉 $、$ Purinmononuclotide, 承顆 粒八 Puxinbasen 7 亦成分トナスモノナルコトラ 決定七リ.

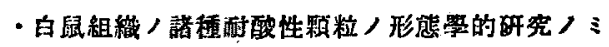
ヨ以テンテハ「タローム政酸性顆粒卜鐵耐酸性頪

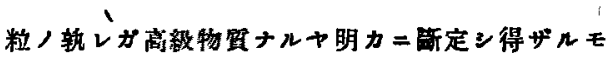
銅顆粓八既避，如既二可成多量二細尿管上皮 $\mathbf{3}$

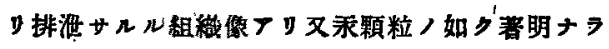
ザルモ稩胞間敦，或八組䋨間戟二無定形八耐酸性

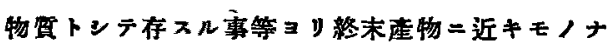

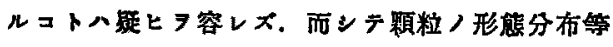

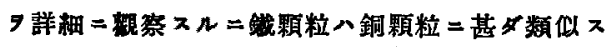
ルモ「クローム䒜粒」ハ銅顆粒トノ間=左程著ンキ 類似點？有七ズ. 從ッテ白鼠二於テモ家鬼ニ於ヶ ルト同栋「タローム顆粒」最モ高极ナル核蛋白二ン

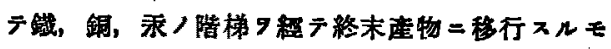
ノト思惟サルルーノナリ。

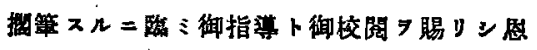

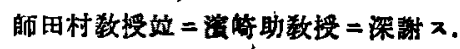

\section{it}

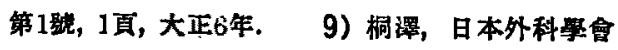

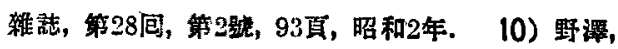

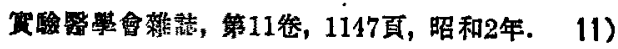
Plato, Arch. für mikr. Anat., Bd. 48, S. 280 ,

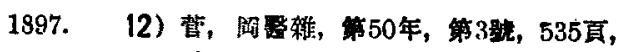

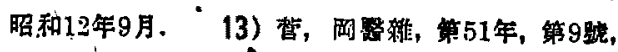
1878面，昭和13年9月. 14）铃木，新鼬㗨大病理

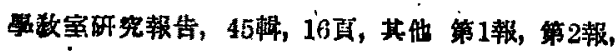
文暗炤: 


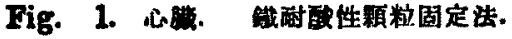

K.F.J. 䜤, Zeise $20 \times 7 \times 35 \mathrm{~cm}$

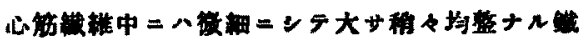

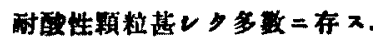

Fig. 2. 舌. 銅矿酸性顆粒固定法. 操作, 溚大，同上.

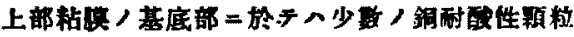

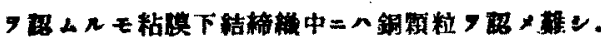

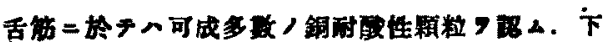

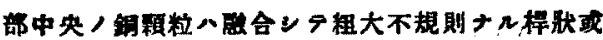

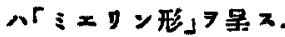

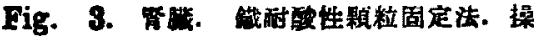
作，城大，同上。

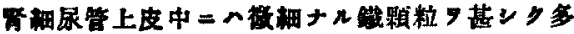

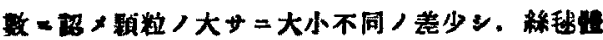

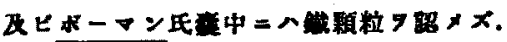

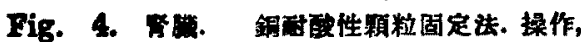
城大，用上。

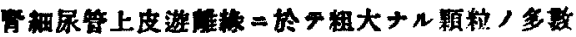

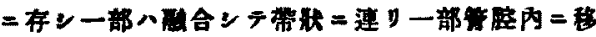

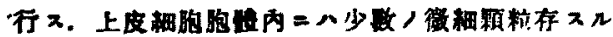

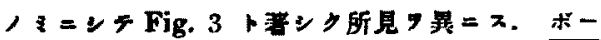

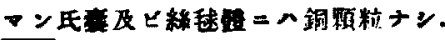

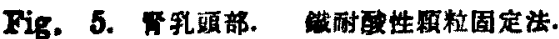
操作, 撒大，同上。

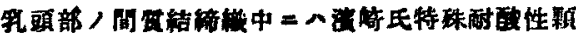

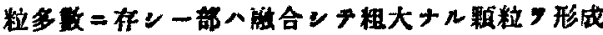
$x$.

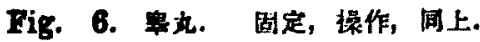
热大, Yeiss $10 \times 7 \times 35 \mathrm{~cm}$

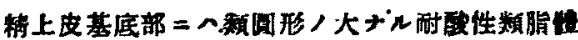

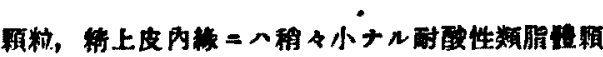

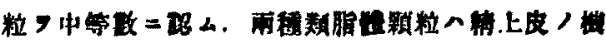

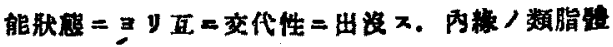

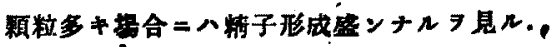

Fig. 7. 䀢. 銅耐酸性顆粒固定法. 操作, 同上. Zeise $40 \times 7 \times 30 \mathrm{~cm}$

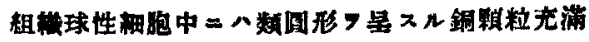

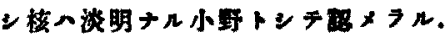

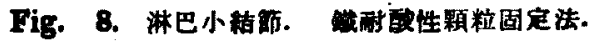
操作，同上. Zeiss $90 \times 7 \times 30 \mathrm{~cm}$.

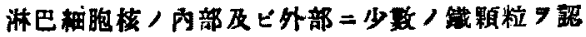
4.

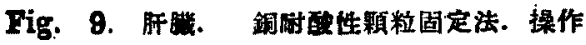
同上. 搷大, Zeiss $20 \times 7 \times 30 \mathrm{~cm}$

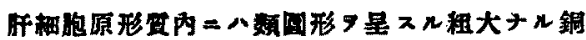

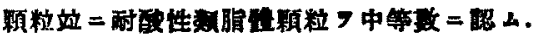

Fig. 10. 小暗. 酸性顆粒固定法. 操作 同上. Zeiss $40 \times 7 \times 30 \mathrm{~cm}$

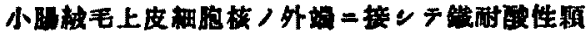

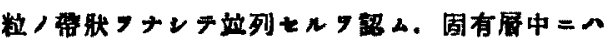

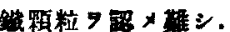

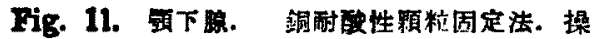
作，提大，同上。

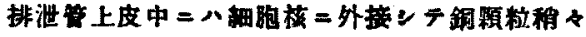

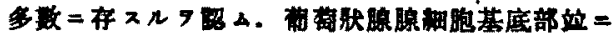

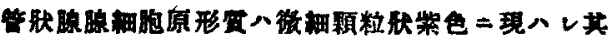

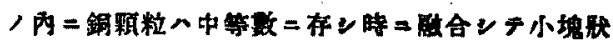

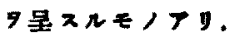

Fig. 12. 舌下腺. 固定, 操作，据大，同上.

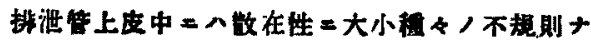

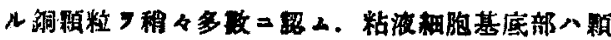

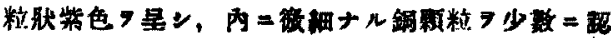


Fig. 1.

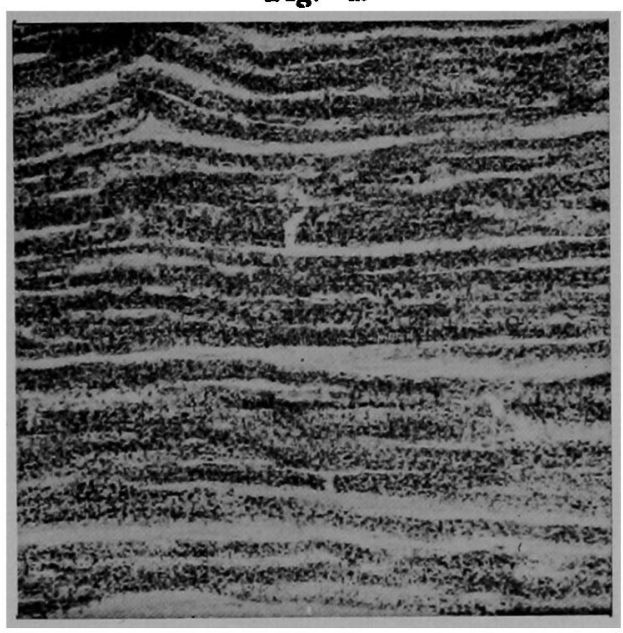

Fig. 3.

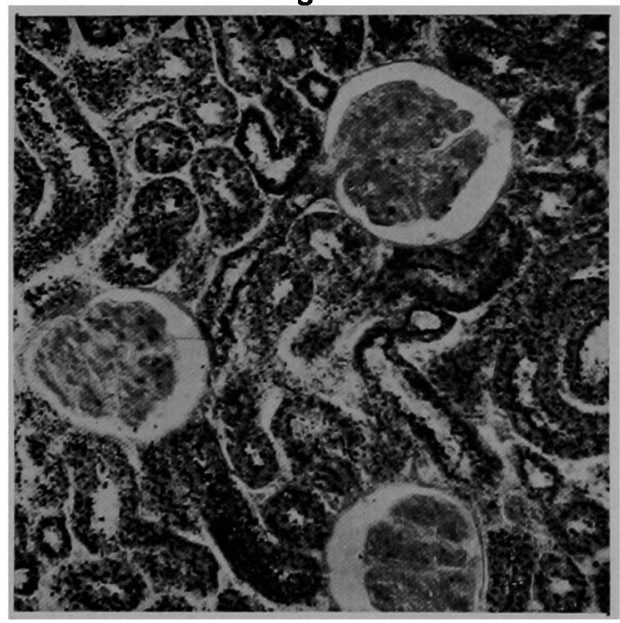

Fig. 5 .

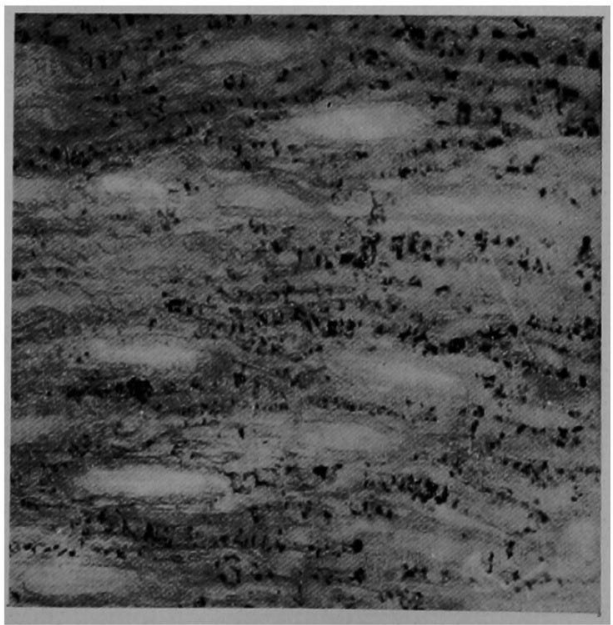

Fig. 2.

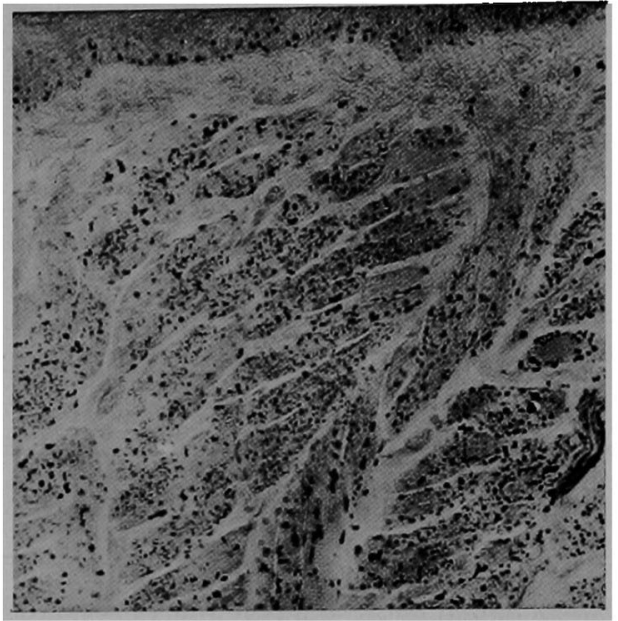

Fig. 4.

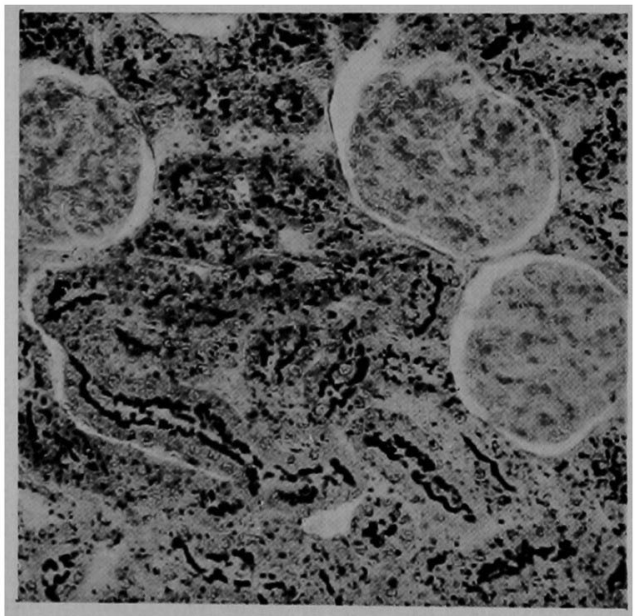

Fig. 6.

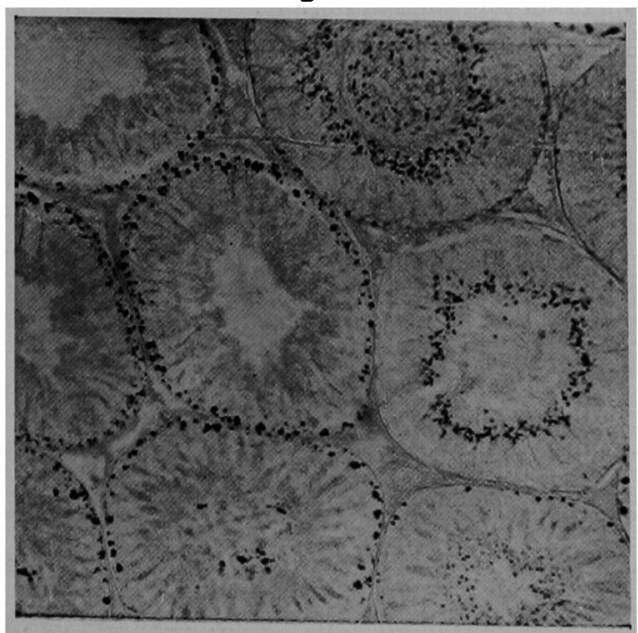


营論 文 附 圖

Fig. 7.

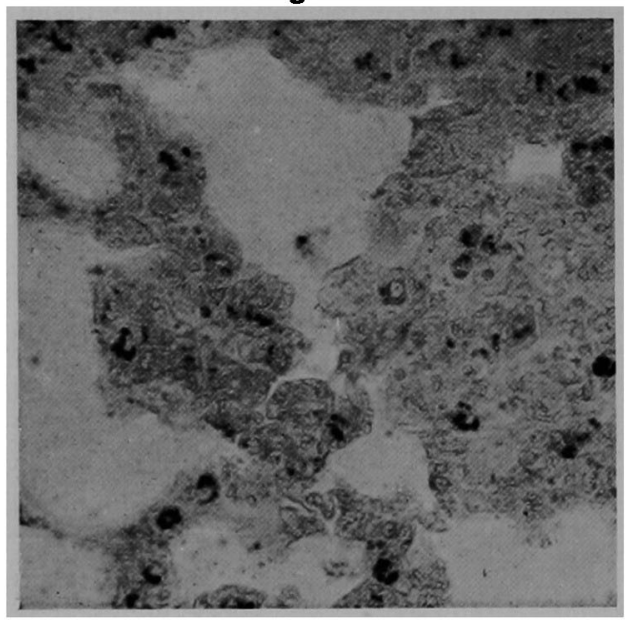

Fig. 9.

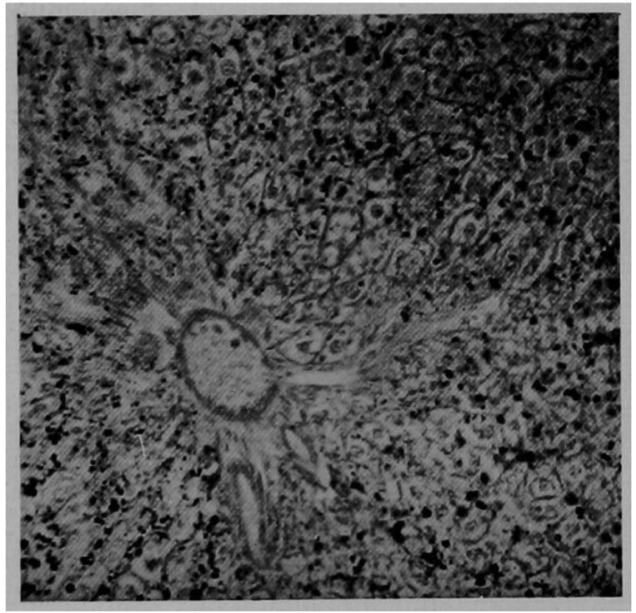

Fig. 11.

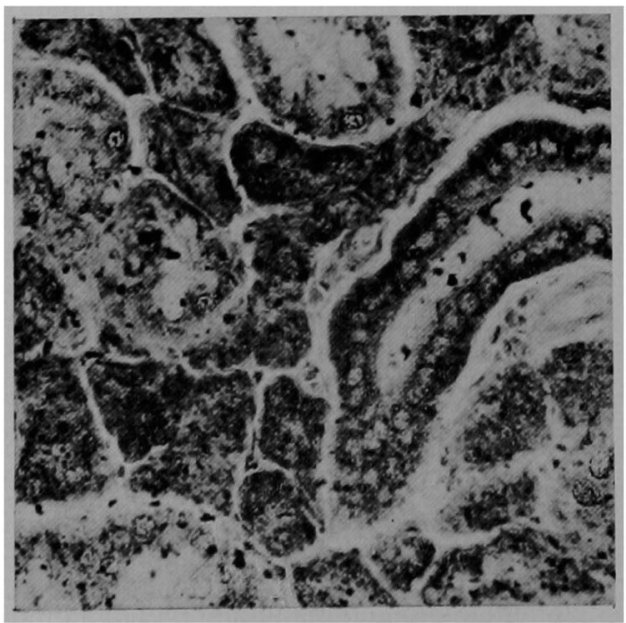

Fig. 8.

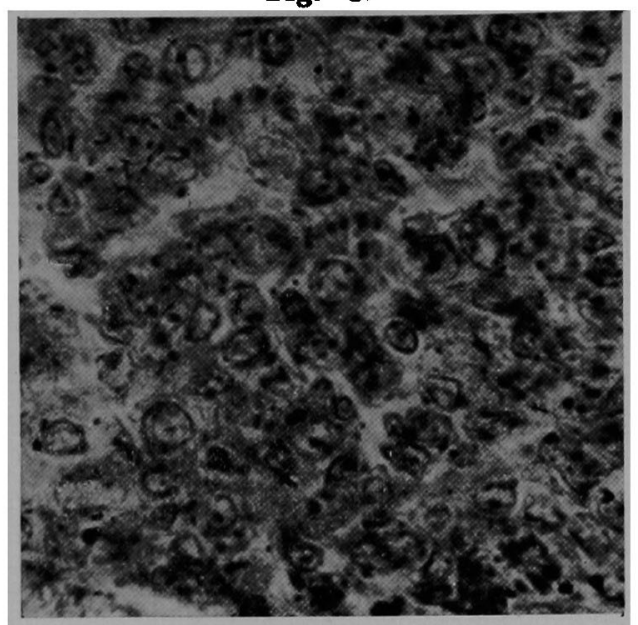

Fig. 10.

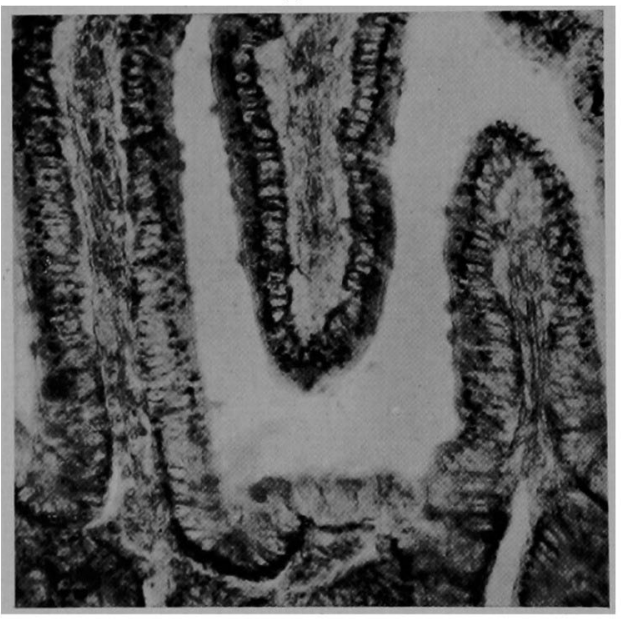

Fig. 12.

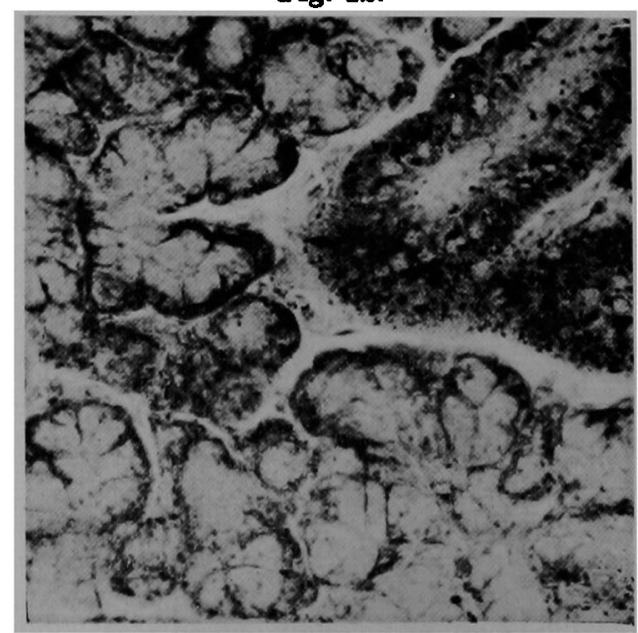


Aus dem Pathologischen Institut der Medizinischen Fakultät Okayama

(Verstand: 'Prof. Dr. O. Tamüra).

\section{Studien über Hamazakische säurefeste Granula bei gesunden Ratten.}

\section{(3. Mitteilung)}

\section{Fe- und Cu.säurefeste Granula.}

\section{Von}

Dr. Yúkio Suga.

Eingegangèn am 7. Oktober 1938.

Hamazaki hat bereits auf Grund seiner chemischen Untersuchungen festgestellt, da $B$ Cr-säurefeste Granula hauptsächlich aus freier tierischer Nucleinsäure, Fe-säurefeste Granula hauptsāchlich aus Purinmononucleotiden, Cu-säurefeste Granula hauptsächlich aus Purinmononucleosiden und Hg-säurefeste Granula zum größten Teil aus Prinbasen 'entstanden sind. Verfasser hat bei gesunden weißen Ratten die oben genannten säurefesten Granula in der Hauptsache vom histologischen Gesichtpunkt aus untersucht und berichtete schon in seiner ersten Mitteilung über die Befunde an Cr-säurefesten Granula und in seiner Zweiten Mitteilung über die an $\mathrm{Hg}$-säuresesten Granula.

In der vorliegenden Mitteilung handelt es sich um histologische Befunde an Hamazakischen Fe- und Cu-säurefesten Granula in verschiedenen Organen und Geweben von gesunden weißen Ratten, worüber im folgenden kurz zusammenfassend berichtet sei :

1) Fe- und Cu-săurefeste Granula haben im allgemeinen eine große morphologische Ähnlichkeit; jede dieser zwei Arten ist jedoch als selbständige Granula anzusehen, weil man in einem bestimmten Gewebe einen deutlichen morphologischen Unterschied zwischen -ibnen finden'kann.

2) Im. Vergleich zu den Fe-säurefesten Granula enthalten die Cu-säurefestèn Granula eine größere Menge Lipoid. Sie sind meistens grob und rundlich.

3) Cu-säurefeste Grapula bzw. Substanzen, die von einem Harnkanälchen ausgesondert werden, sind ein Bestandteil des Hams.

4) Auf Grund des oben Gesagten stimmt Verf. der Hamazakischen Ansicht zu, daß die Cu-säurefesten Granula den Hg-säurefesten Granula am ähnlichsten sind und deshalb als eine dem Endprodukte des Stofiwechsels sehr nahe stehende Substanz anzusehen sind.

5) Die Histiocyten in den Alveolarsepten der weißen Ratten, anders als die in anderen Geweben, enthalten zohlreiche Cu-säurefeste Granula, sodaß sie beim Stoff-' wechsel der säurefesten Substanzen, eine spezilische Rolle spielen. 
6) Im geschichteten Plattenepithel sind im allgemeinen nur wenige sāurefeste Substanzen vorhanden, mit Ausnahme der Cu-säurefesten Substanzen, welche in der Schleimhaut des Vordermagens in einer bestimmten Lagebeziehung zu dem Histon stehen.

Die Oben genanten 4 Arten von säurefesten Granula bzw. Substanzen Haimazakis zeigen bei weißen Ratten je nach der Art des Bchwermetalls, die zur Fixation des Gewebs dient, einen deutlichen morphologischen Unterscheid; die säurefesten Lipoidgranula. weisen aber, unabhängig vom Fixations verf̣ahren, ein fast gleiches Gewebsbild auf.' Es besteht kein $Z$ weifel darüber, daB die säurefesten Granula in verschiedenen Geweben, sowohl bei weißen Ratten wie bei Kaninchen, die säurefesten Granula von Exogen sind und demgema $B$ die von Endogen produzierten säurefesten Granula äußerst selten sind. Wenn man aber die Herkunft der säurefesten Granula überhaupt und ihre biologische Bedeutung genauer untersuchen will, so ist die Forschung der endogenen säurefesten Granula durchaus nicht entbehrlich.

Cr-säurefeste Granula werden an der Schleimbaut des untern Teils des Osophagus, an der Schleimhaut des Magens sowie des Dünndarms und an den Leberzellen im Zellkerne Nachgewiesen : Fe- sowie Cu-säurefeste Granula zeigen sich ebenfalls im Zellkerne der Lymphdrüse, der Vorderhornzelle des Rückenmarks, der Basalzelle der Zungenschleimhaut, der Epithelzelle des vorderen Magenteils und der Leberzelle. Was die säurefesten Granula, die um den Zellkern umschrieben sind, anbetrifft, so sind sie überall zu bemerken. Wie bereits in der 2. Mitteilung berichtet wurde, wiesen die $\mathrm{Hg}$-8äurefesten Granula in der Drüsenzelle einen beachtenswerten spezifischen Befund auf (Cf. 2. Mitt.).

Alle solche in einer bestimmten Positionsbeziehung zum Zellkerne stehenden Granula scheinen sich nicht nur als ein Nucleinstoffwechselprodukt, sondern sls eine solche Substanz zu präsentieren, die zu einem bestimmten physiologischen' $Z$ wéck durch die. physiologische Funktion exzeugt wird. (Autoreferat) 